ROCZNIK PRZEMYSKI t. 57

HISTORIA z.1 (26) 2021

KS. DR MARCIN KAPEON (Przemyśl)

orcid.org/0000-0002-7461-1715

\title{
KSIĄDZ DOKTOR JAN KWOLEK I JEGO ZASŁUGI DLA ARCHIWISTYKI KOŚCIELNEJ
}

\author{
Abstract \\ REVEREND DOCTOR JAN KWOLEK AND HIS SERVICES TO CHURCH ARCHIVAL STUDIES
}

The paper shows the life of Rev. Jan Kwolek, an outstanding priest from the Przemyśl Diocese and a man of broad intellectual horizons, with regard to his work at the Archdiocesan Archive in Przemyśl. The article consists of three parts showing Reverend Kwolek's life, an outline of the history of Polish archive resources, finally - the enormous effort the priest had put into proper organizing and functioning of this institution.

Keywords: Rev. Jan Kwolek, Archdiocesan Archive in Przemyśl, archival studies, Przemyśl Diocese

Słowa kluczowe: ks. Jan Kwolek, Archiwum Archidiecezjalne w Przemyślu, archiwistyka, diecezja przemyska.

\section{Wstęp}

Najważniejszym sensem istnienia każdej diecezji jako części Kościoła Powszechnego jest troska o życie religijne mieszkających na jej obszarze katolików. Pierwszą osobą odpowiedzialną za tę kwestię, jest stojący na jej czele biskup, który - chcąc właściwie wywiązywać się z powierzonych sobie zadań - potrzebuje szeregu współpracowników wypełniających swoje obowiązki przede wszystkim w kurii (do 1917 r. nazywanej konsystorzem), jak i w innych instytucjach diecezjalnych. Z tego też względu tak ważna jest polityka personalna ordynariusza, który, dobierając osoby odpowiedzialne za poszczególne dziedziny życia eklezjalnego, wpływa na ocenę przez potomnych i swoich rządów. Niniejszy artykuł ma na celu ukazanie jednego ze współpracowników biskupa, który, jako młody absolwent studiów prawniczych w Rzymie w 1915 r., stanął w drzwiach sądu biskupiego, a rok później został sekretarzem konsystorza. Ksiądz Jan Kwolek - bo o nim mowa 
- od tego momentu na trwałe zapisał się w historii diecezji przemyskiej nie tylko jako prawnik i kurialista, ale też jako człowiek o szerokich horyzontach intelektualnych i wielu zainteresowaniach, wśród których na pierwszym miejscu należy wymienić archiwistykę. Właśnie tej jego pasji, jak wynika z tytułu, poświęcono tenże artykuł i choć nie była ona wprost związana z uzyskanym wykształceniem, to jednak przyniosła wiele pożytku nie tylko diecezji przemyskiej, ale również Kościołowi w Polsce. Artykuł składa się z trzech części, ukazujących życiową drogę ks. J. Kwolka, krótki zarys historii przemyskich archiwaliów i archiwum, a w końcu podkreśla ogrom pracy włożonej przez niego w prawidłowe zorganizowanie i funkcjonowanie tej instytucji.

\section{Droga życia}

Ksiądz J. Kwolek urodził się 13 grudnia 1885 r. w Kraczkowej w rodzinie rolniczej, jako syn Sebastiana i Katarzyny z domu Peszko'. W latach 1896-1904 był uczniem I Gimnazjum w Rzeszowie, gdzie 15 czerwca 1904 r. uzyskał świadectwo dojrzałości². Następnie studiował na Wydziale Filozoficznym Uniwersytetu Lwowskiego (1904-1906)3 ${ }^{3}$, by po dwóch latach wstąpić do Seminarium Duchownego w Przemyślu, gdzie 29 czerwca 1910 r. przyjął święcenia kapłańskie i rozpoczął pracę wikariusza w parafii Cieklin ${ }^{4} .28$ października 1910 r. bp Józef Sebastian Pelczar mianował go tam administratorem ${ }^{5}$. Miesiąc później objął placówkę wikariuszowską w Dobromilu (1 grudnia 1910 - 31 października 1912) ${ }^{6}$, a jesienią 1912 r. rządca diecezji wysłał go do Rzymu w celu podjęcia studiów prawniczych na Uniwersytecie Gregoriańskim ${ }^{7}$. Zwieńczył je doktoratem 20 lipca $1914 \mathrm{r}^{8}$ Po powrocie do diecezji przemyskiej, ze względu na działania wojenne do końca sierpnia 1915 r., przebywał w rodzinnej miejscowości ${ }^{9} .2$ września 1915 r. władze diecezjalne mianowały go prefektem studiów w Seminarium Duchownym w Przemyślu i pomocnikiem katechety I Gimnazjum w Przemyślu ${ }^{10}$, a 8 listopada

${ }^{1}$ Archiwum Archidiecezjalne w Przemyślu (dalej: AAPrz), sygn. APK TP ks. Kwolek Jan, Teczka służbowa ks. Jana Kwolka, Testimonium ortus et baptismi (copia), b. sygn.

${ }^{2}$ Ibidem, Świadectwo dojrzałości ks. Jana Kwolka; J. Świeboda, Dzieje I Gimnazjum w Rzeszowie w latach 1786-1918, Rzeszów 1984, s. 215.

${ }^{3}$ AAPrz, sygn. APK TP ks. Kwolek Jan, Teczka służbowa ks. Jana Kwolka, Świadectwo odejścia z Uniwersytetu we Lwowie z dnia 15 VII $1907 \mathrm{r}$.

${ }^{4}$ Ibidem, Tabela służbowa ks. Jana Kwolka, b. sygn.

${ }^{5}$ Ibidem, sygn. APK TP ks. Kwolek Jan, Teczka służbowa ks. Jana Kwolka, Nominacja na administratora parafii Cieklin z dnia 28 X $1910 \mathrm{r}$.

${ }^{6}$ Ibidem, Tabela służbowa ks. Jana Kwolka, b. sygn.

${ }^{7}$ Ibidem, sygn. APK TP ks. Kwolek Jan, Teczka służbowa ks. Jana Kwolka, Pismo bpa Józefa Sebastiana Pelczara do ks. Jana Kwolka z dnia 21 X 1912 r.

${ }^{8}$ Ibidem, Dyplom doktorski ks. Jana Kwolka z dnia 20 lipca 1914 r.

${ }^{9}$ T. Śliwa, Kwolek Jan, [w:] Stownik polskich teologów katolickich 1918-1981 (dalej: SPTK), t. 6, red. L. Grzebień, Warszawa 1983, s. 293.

${ }^{10}$ AAPrz, sygn. APK TP ks. Kwolek Jan, Teczka służbowa ks. Jana Kwolka, Pismo bpa Józefa Sebastiana Pelczara do ks. Jana Kwolka z dnia 2 IX 1915 r. 
tego roku został sekretarzem w sądzie małżeńskim biskupim (pełnił tę funkcję do 4 stycznia 1924 r. $)^{11}$. Z dniem 31 sierpnia 1916 r. ks. J. Kwolek został uwolniony od obowiązków prefekta seminarium i zastępcy katechety, a mianowany sekretarzem konsystorza $^{12}$. Równocześnie od 15 marca 1917 do 31 sierpnia 1918 r. ponownie pełnił funkcję zastępcy katechety w I Gimnazjum w Przemyślu ${ }^{13}$. Obowiązki sekretarza konsystorza wykonywał do 18 sierpnia 1918 r., a dzień później mianowano go notariuszem kurii biskupiej, odpowiedzialnym również za jej archiwum ${ }^{14}$. Od 1918 do 1958 r. był profesorem prawa kanonicznego w Diecezjalnym Instytucie Teologicznym, wykładał również sztukę kościelną ${ }^{15}$. W styczniu 1924 r. został sędzią sądu biskupiego (sprawował tę funkcję do 1934 r.) ${ }^{16}$, a 20 października 1927 r. mianowano go również Dyrektorem Archiwum Diecezjalnego ${ }^{17}$. Od 1 stycznia 1933 r. pełnił funkcję kanclerza kurii, po czym 31 sierpnia 1934 r. wniósł rezygnację $^{18}$. Od 22 maja 1934 r. do śmierci sprawował urząd oficjała sądu biskupiego ${ }^{19}$.

To tylko najważniejsze urzędy pełnione przez ks. Kwolka, a oprócz nich zaangażowany był w szereg pomniejszych inicjatyw czy też gremiów. Od 1927 r. był egzaminatorem prosynodalnym, a od $1955 \mathrm{r}$. sędzią i egzaminatorem synodalnym $^{20}$. W $1930 \mathrm{r}$. wszedł w skład diecezjalnej rady administracyjnej ${ }^{21}$, w $1933 \mathrm{r}$. diecezjalnej rady Akcji Katolickiej²2, a w 1945 r. w skład komisji diecezjalnej dla spraw organistowskich ${ }^{23}$. Ponadto należał do diecezjalnej komisji artystycznej i budowlanej oraz komisji mieszanej do spraw konserwacji zabytków ${ }^{24}$. Dodać

\footnotetext{
${ }^{11}$ Ibidem, Pismo bpa Józefa Sebastiana Pelczara do ks. Jana Kwolka z dnia 8 XI 1915 r.; T. Śliwa, Kwolek Jan, s. 293.

${ }^{12}$ AAPrz, Pismo bpa Józefa Sebastiana Pelczara do ks. Jana Kwolka z dnia 1 VIII 1916 r.

${ }^{13}$ Ibidem, Pismo c. k. Rady szkolnej krajowej do ks. Jana Kwolka z dnia 14 III 1917 r.; ibidem, Tabela służbowa ks. Jana Kwolka.

${ }^{14}$ Ibidem, Pismo bpa Józefa Sebastiana Pelczara do ks. Jana Kwolka z dnia 19 sierpnia 1918 r.; ibidem, Tabela służbowa ks. Jana Kwolka, b. sygn.

${ }^{15}$ Ibidem, APK TP ks. Kwolek Jan, Pismo bpa Karola Józefa Fischera (biskupa sufragana i wikariusza generalnego) do ks. Jana Kwolka z dnia 20 IX 1918 r.; T. Śliwa, Kwolek Jan, s. 293.

${ }^{16}$ AAPrz, APK TP ks. Kwolek Jan, Pismo bpa Józefa Sebastiana Pelczara do ks. Jana Kwolka z dnia 5 I 1924 r.; F. Persowski, Kwolek Jan, [w:] Polski stownik biograficzny (dalej: PSB), t. 16, red. E. Rostworowski, Wrocław-Warszawa-Kraków 1971, s. 387.

${ }^{17}$ AAPrz, APK TP ks. Kwolek Jan, Pismo bpa Anatola Nowaka do ks. Jana Kwolka z dnia 20 X $1927 \mathrm{r}$.

${ }^{18}$ Ibidem, Pismo bpa Anatola Nowaka do ks. Jana Kwolka z dnia 1 I 1933 r.; ibidem, Pismo bpa Franciszka Bardy do ks. Jana Kwolka z dnia 17 VIII 1934 r.

${ }^{19}$ Ibidem, Pismo bpa Franciszka Bardy do ks. Jana Kwolka z dnia 22 maja 1934 r.

${ }^{20}$ Ibidem, Tabela służbowa ks. Jana Kwolka, b. sygn.

${ }^{21}$ J. Ataman, Ks. Jan Kwolek 1885-1958, „Archiwa, Biblioteki i Muzea Kościelne” (dalej: ABMK), t. 1, z. 1, Lublin 1959, s. 160.

${ }^{22}$ AAPrz, sygn. APK TP ks. Kwolek Jan, Pismo bpa Anatola Nowaka do ks. Jana Kwolka z dnia 24 III $1933 \mathrm{r}$.

${ }^{23}$ Ibidem, Pismo bpa Franciszka Bardy do ks. Jana Kwolka z dnia 18 X 1945 r.

${ }^{24}$ Schematismus universi venerabilis cleri saecularis et regularis dioecesis premisliensis rit. lat. pro anno Domini 1932, Premisliae 1932, s. 22; Rocznik diecezji przemyskiej ob. tac. na rok 1938, Przemyśl 1938, s. 21.
} 
należy, że kompetencje ks. Kwolka dostrzeżono również poza diecezją przemyską. W grudniu 1922 r. Senat Uniwersytetu Lubelskiego na wniosek Wydziału Prawa Kanonicznego zaproponował mu podjęcie wykładów z tej dyscypliny ${ }^{25}$. Po konsultacjach z biskupem J. S. Pelczarem przemyski kanonista jednakże odmówił, gdyż rządca diecezji nie chciał zwolnić go z dotychczasowych obowiązków, a ponadto zamierzał prowadzić prace archiwalne ${ }^{26}$.

Zaangażowanie ks. J. Kwolka zostało docenione przez władze diecezjalne stosownymi odznaczeniami. Już 29 maja 1918 r. bp J. S. Pelczar wyróżnił go Expositorio Canonicalis ${ }^{27}$, a 5 stycznia 1924 r. przywilejem rokiety i mantoletu ${ }^{28}$. W $1931 \mathrm{r}$. otrzymał godność podkomorzego papieża Piusa $\mathrm{XI}^{29}$. W roku następnym wszedł do kapituły przemyskiej ${ }^{30}$, w 1947 r. został podkomorzym papieża Piusa XII ${ }^{31}$, a od 1951 r. piastował w kapitule godność prałata scholastyka ${ }^{32}$.

Ksiądz J. Kwolek należał również do kilku towarzystw naukowych. W Przemyślu było to Towarzystwo Przyjaciół Nauk (w 1945 r. został na krótko jego dyrektorem naczelnym), w tym mieście był też współzałożycielem oddziału Polskiego Towarzystwa Historycznego (pełnił funkcję wiceprezesa). Angażował się również w organizację Związku Zakładów Teologicznych w Polsce ${ }^{33}$. W 1925 r. departament sztuki Ministerstwa Wyznań Religijnych i Oświecenia Publicznego mianował ks. Kwolka członkiem-korespondentem Komisji Konserwatorskiej przy Urzędzie Wojewódzkim we Lwowie ${ }^{34}$, a w 1928 r. powołano go do pełnienia funkcji członka-korespondenta Komisji Historycznej Polskiej Akademii Umiejętności ${ }^{35}$. Współpracował również z wydawnictwem Polskiego słownika biograficznego i Encyklopedii kościelnej. Sam dość sporo opublikował, m.in. wydał w 1949 r. Atlas historyczny biskupstw polskich ${ }^{36}$.Zmarł 20 maja 1958 r. w Przemyślu. Ciało zostało przeniesione do kościoła Najświętszego Serca Jezusowego, a 22 maja do katedry ${ }^{37}$. Pogrzeb odbył się dzień później na cmentarzu przy ul. J. Słowackiego ${ }^{38}$.

${ }^{25}$ AAPrz, sygn. APK TP ks. Kwolek Jan, Pismo ks. Antoniego Szymańskiego wicerektora Uniwersytetu Lubelskiego do ks. Jana Kwolka z dnia 7 XII 1922 r.

${ }^{26}$ Ibidem, Pismo ks. Jana Kwolka do wicerektora Uniwersytetu Lubelskiego z dnia 10 XII 1922 r. [minuta].

${ }^{27}$ Ibidem, Pismo bpa Józefa Sebastiana Pelczara do ks. Jana Kwolka z dnia 29 V 1918 r.

${ }^{28}$ Ibidem, Pismo bpa Józefa Sebastiana Pelczara do ks. Jana Kwolka z dnia 5 I 1924 r.

${ }^{29}$ Ibidem, Pismo z Sekretariatu Stanu Stolicy Apostolskiej do ks. Jana Kwolka z dnia 5 II 1931 r.

${ }^{30}$ Ibidem, Nominacja ks. Jana Kwolka z dnia 1 IV 1932 r.

${ }^{31}$ Ibidem, Pismo z Sekretariatu Stanu Stolicy Apostolskiej do ks. Jana Kwolka z dnia 15 II 1947 r.

${ }^{32}$ Ibidem, Pismo kardynała Stefana Wyszyńskiego do ks. Jana Kwolka z dnia 31 X 1951 r.

${ }^{33}$ T. Śliwa, Kwolek Jan, s. 293.

${ }^{34}$ AAPrz, APK TP ks. Kwolek Jan, Pismo Ministra Wyznań Religijnych i Oświecenia Publicznego do ks. Jana Kwolka z dnia 28 VII 1925 r.

${ }^{35}$ Ibidem, Tabela służbowa ks. Jana Kwolka, b. sygn.

${ }^{36}$ F. Persowski, Kwolek Jan, s. 387-388.

${ }^{37}$ S. Momidłowski, Wspomnienia pośmiertne: Śp. ks. dr Jan Kwolek, „Kronika Diecezji Przemyskiej" (dalej: KDP) 1958, R. 44, z. 9-10, s. 272.

${ }^{38}$ AAPrz, APK TP, ks. Kwolek Jan, Nekrolog ks. Jana Kwolka. 
Zapoznając się z życiorysem ks. J. Kwolka nie sposób nie zauważyć, że w swojej aktywności na rzecz diecezji przemyskiej w znacznej mierze poświęcił się pracy w jej archiwum. To właśnie ten aspekt jego działalności został zawarty w niniejszym artykule. Chcąc jednak oddać specyfikę tego zajęcia, warto na początku naświetlić krótkim rys historyczny instytucji, dla której rozwoju nie szczędził swoich sił i zdolności.

\section{Dzieje archiwaliów i archiwum przemyskiego}

Archiwum diecezjalne w Przemyślu ze względu na bogactwo swoich zasobów należało i należy do jednych z ważniejszych placówek tego typu w Polsce, chociaż trzeba zauważyć, że II wojna światowa w znaczny sposób jego zbiory uszczupliła. Początki tej instytucji należy wiązać z powstaniem diecezji przemyskiej (1375 r.) i rozpoczęciem rządów pierwszego jej biskupa, który z całą pewnością posiadał kancelarię wytwarzającą akta urzędowe, jak i przechowującą dokumenty czy przywileje uzyskane z zewnątrz ${ }^{39}$. Akta bieżącego urzędowania były podzielone na Acta Episcopalia, spisywane w miejscu przebywania biskupa i z czasem przesyłane do Przemyśla, jak również Acta Officialatus, spisywane w kurii przez jednego z kanoników zastępującego w sprawach urzędowych biskupa. $Z$ biegiem lat obydwa rodzaje ksiąg gromadzono wspólnie, nadając im układ chronologiczny, jednakże upływające wieki nie sprzyjały ich przechowywaniu, stąd też już w XVII w. wiele z nich uważano za zaginione na skutek klęsk żywiołowych, najazdów, wojen, jak również niesumienności kościelnych urzędników ${ }^{40}$. Te, które ocalały, wymagały uporządkowania. Pracę tę rozpoczął ks. Fryderyk Alembek ${ }^{41}$, który w księdze pt. Collectanea librorum consistorialium zawarł wyciągi z 27 ksiąg konsystorskich (23 z ksiąg aktów oficjalatu z lat 1466-1646 i cztery z ksiąg aktów biskupich z lat 1486-1570 $)^{42}$. Inna napisana przez niego książka pt. Trzebiniana zawiera regesty dokumentów biskupstwa i kapituły ${ }^{43}$.

Po śmierci ks. F. Alembeka nastała epoka, w trakcie której zginęło wiele akt konsystorskich. Przyczyną tego znowu były wojny i najazdy, co wymuszało potrzebę

\footnotetext{
${ }^{39}$ J. Kwolek, Archiwa diecezji przemyskiej ob. łac., Przemyśl 1927, s. 6-7.

${ }^{40}$ Idem, Archiwum diecezjalne przy Kurii Biskupiej ob. łac. w Przemyślu, Włocławek 1936, s. 3.

${ }^{41}$ Alembek (Alnpech) Fryderyk - urodził się 13 X 1598 r. we Lwowie. W 1622 r. uzyskał w Akademii Krakowskiej bakalaureat sztuk wyzwolonych, a w 1634 r. doktorat z filozofii i teologii. W 1620 r. przyjął święcenia niższe. W 1624 r. mimo tylko niższych święceń otrzymał prezentę na probostwo w Żurawicy, a w tym samym roku przyjął święcenia kapłańskie. Dnia 26 X 1634 r. został dziekanem zewnętrznym przemyskim, a w $1635 \mathrm{r}$. kanonikiem honorowym przemyskim. Od $1643 \mathrm{r}$. przemyski kanonik katedralny fundi Pnikut, a dziesięć lat później mianowany protonotariuszem apostolskim. Pełnił funkcję wikariusza w sprawach duchowych i oficjała generalnego bpa Pawła Piaseckiego i bpa Andrzeja Trzebickiego. Zmarł w 1672 r. Zob. J. Kwolek, Alembek (Alnpech), [w:] PSB, t. 1, Kraków 1935, s. 73-74; F. Pawłowski, Prałaci i kanonicy Kapituły Katedralnej obrządku tacińskiego w Przemyślu, przekład Z. Trojnar, Przemyśl 2018, s. 16-25; E. Ozorowski, Alembek Fryderyk, [w:] SPTK, t. 1, red. H. E. Wyczawski, Warszawa 1981, s. 45-46.

42 J. Patryn, Archiwistyczna działalność ks. Jana Kwolka (1918-1955), Lublin 1985, s. 24 [mps w Bibliotece Wyższego Seminarium Duchownego w Przemyślu].

${ }^{43}$ J. Kwolek, Archiwa diecezji przemyskiej, s. 7.
} 
ukrywania akt, a co za tym idzie ich przemieszczanie. Nie sprzyjały im klęski żywiołowe, jak również tymczasowość władzy biskupiej i prowadzenie przez nich niejednokrotnie odrębnej kancelarii poza Przemyślem ${ }^{44}$.

Na początku XVIII w. sporo uwagi archiwum poświęcił ks. Błażej Stanisław Chodziński ${ }^{45}$, który oprawiał zniszczone tomy, zaopatrując wiele z nich w paginację, a także kontynuował Collectanea $\mathrm{F}$. Alembeka ${ }^{46}$. Inny notariusz konsystorza ks. Kazimierz Antoni Sandorski ${ }^{47}$ również oprawił wiele ksiąg, nadając im paginację, ponadto zredagował akta wizytacji dokonanej przez bpa Krzysztofa Jana Szembeka ${ }^{48}$ w latach $1720-1723$ i dołączył do nich kopie dokumentów z archiwów wizytowanych parafii. Całość tego dzieła nosi tytuł Iura ecclesiarum. Poza tym ks. K. Sandorski skopiował w dwóch księgach dokumenty biskupstwa i kapituły, tytułując je Rosa (na cześć bpa Szembeka herbu Róża) ${ }^{49}$.

Po utracie przez Rzeczpospolitą niepodległości, pierwsze pół wieku rządów austriackich na terenie diecezji przemyskiej to czas ogromnego spustoszenia archiwaliów kościelnych. Władze zaborcze utworzyły we Lwowie tabulę ziemską, która, dążąc do ustalenia stanu prawnego beneficjów, nakazała instytucjom kościelnym przesyłanie odpowiednich dokumentów. $\mathrm{Z}$ tego powodu wiele $\mathrm{z}$ nich znalazło się we Lwowie i choć w 1827 r. Gubernium galicyjskie część dokumentów zwróciło, to jednak sporo zaginęło lub weszło w posiadanie świeckich archiwów Wiednia i Lwowa ${ }^{50}$.

${ }^{44}$ J. Patryn, op. cit., s. 24-25; J. Kwolek, Archiwa diecezji przemyskiej, s. 9-10.

${ }^{45}$ Błażej Stanisław Chodziński - szlachcic, od 27 I 1706 r. pełnił obowiązki notariusza publicznego za rządów bpa Jana Bokuma. Zmarł przed 28 X, a po $13 \mathrm{~V} 1718$ r. Zob. M. Kociubiński, Księża diecezji przemyskiej obrządku łacińskiego, t. 1, wstęp i opr. Z. Budzyński, Przemyśl 1988-1989, s. 60 [mps w AAPrz]; J. Kwolek, Archiwa diecezji przemyskiej, s. 10.

${ }^{46} \mathrm{~J}$. Kwolek, Archiwa diecezji przemyskiej, s. 10.

${ }^{47}$ Kazimierz Antoni Sandorski - doktor obojga praw, 26 VI 1719 r. mianowany notariuszem kurii biskupiej. Około 1721 r. przyjął świecenia kapłańskie, wówczas został też notariuszem publicznym apostolskim. Od czerwca 1724 r. kanonik kolegiaty w Brzozowie i pierwszy jej kustosz, a od 21 X 1726 r. honorowy kanonik katedry przemyskiej, gdzie od 1728 r. spełniał obowiązki sekretarza. Ponadto pełnił funkcję proboszcza w Strachocinie i Ujkowicach oraz altarzysty w kolegiacie jarosławskiej. Protonotariusz apostolski, który ostatecznie osiadł przy szpitalu Świętego Ducha w Przemyślu jako jego prepozyt. Zmarł przed 5 XII 1750 r. Zob. M. Kociubiński, op. cit., s. 440-441; J. Kwolek, Archiwa diecezji przemyskiej, s. 11-12.

${ }^{48}$ Krzysztof Andrzej Jan Szembek - urodził się 16 V 1680 r. w Słupowie k. Miechowa, studia odbył na Uniwersytecie Jagiellońskim w Krakowie oraz w Ingolstadzie i Padwie, uzyskując doktorat obojga praw. W 1700 r. rozpoczął pracę w kancelarii królewskiej. W latach 1713-1719 był biskupem chełmskim, od 1719 do 1724 r. - przemyskim, a następnie warmińskim. Zmarł 16 III 1740 r. w Lidzbarku Warmińskim i został pochowany w katedrze fromborskiej. Zob. E. Gigilewicz, Szembek Krzysztof Jan, [w:] Encyklopedia Katolicka (dalej: EK), t. 19, red. E. Gigilewicz, Lublin 2013, kol. 37-38; idem, Krzysztof Andrzej Jan Szembek herbu Szembek, [w:] Arcybiskupi i biskupi przemyscy. Słownik biograficzny, red. A. Szal, H. Borcz, M. Kapłon, S. Zych, Przemyśl-Rzeszów 2021, s. 155-159; P. Nitecki, Biskupi Kościoła w Polsce. Stownik biograficzny, Warszawa 1992, s. 201.

${ }^{49}$ J. Kwolek, Archiwum Diecezjalne przy Kurii Biskupiej ob. łac. w Przemyślu, „Ateneum kapłańskie", t. 38: 1936, s. 515; Archiwa Kościoła katolickiego w Polsce. Informator, oprac. M. Dębowska, Kielce 2002, s. 83.

${ }^{50}$ J. Kwolek, Archiwum Diecezjalne przy Kurii Biskupiej, s. 515. 
W latach dwudziestych XIX w. archiwaliami diecezjalnymi zainteresował się ówczesny kanonik kapituły, a następnie biskup Michał Korczyński ${ }^{51}$, który jeszcze w 1820 r. opracował na podstawie dokumentów z archiwum kapitulnego księgę dóbr kapituły ${ }^{52}$. Założył on również kwartalnik teologiczny Przyjaciel Chrześcijańskiej Prawdy, w którym między innymi pojawiały się artykuły z dziejów diecezji na podstawie dokumentów archiwalnych. Te ostatnie niejednokrotnie były przedrukowane $\mathrm{w}$ całości ${ }^{53}$. Już jako biskup polecił oprawić wiele ksiąg, nadać im paginację i indeksy, a ówczesnego kanclerza konsystorza ks. Andrzeja Urba$\mathrm{na}^{54}$ zobowiązał do sporządzenia katalogu zawierającego wykaz ksiąg wizytacji generalnych ${ }^{55}$. Z racji na historyczne wykształcenie życzliwym okiem na sprawy archiwalne spoglądał następca bpa M. Korczyńskiego - bp Franciszek Ksawery Zachariasiewicz ${ }^{56}$, który zwracał się do lwowskiego fiskusa z prośbą o zwrot przesłanych niegdyś i zagubionych ksiąg wizytacji Alembeka i Szembeka. Działania te jednakże okazały się bezowocne. W tej sytuacji w 1843 r. polecił, by konsystorz posiadał księgę, w której zapisywano wszystkie przesłane władzom austriackim dokumenty. Tenże biskup sam zajmował się pracą naukową, jak również zachęcał

${ }^{51}$ Michał Korczyński - urodził się 13 XII 1784 r. w folwarku Tarnowiec (wieś Podleszany) w rodzinie szlacheckiej. Po ukończeniu Gimnazjum w Przemyślu i filozofii we Lwowie w 1805 r. rozpoczął studia teologiczne w Seminarium Generalnym w tym mieście jako alumn diecezji przemyskiej. Po roku wysłano go do Wiednia, gdzie w 1808 r. obronił doktorat z teologii. Wcześniej, bo 15 I 1808 r. otrzymał święcenia kapłańskie. Po powrocie do Przemyśla został sekretarzem w konsystorzu biskupim, następnie katechetą gimnazjalnym i zarządcą majątku kapitulnego. W $1812 \mathrm{r}$. został proboszczem w Zgórsku k. Mielca, a w 1817 r. kanonikiem gremialnym kapituły katedralnej w Przemyślu. Od 1834 r. biskup przemyski. Zmarł 8 X 1839 r. w Przemyślu, gdzie pochowano go na miejskim cmentarzu. Zob. R. Leszczyński, Korczyński Michał Tomasz Wincenty, [w:] PSB, t. 14, Wrocław 1968-1969, s. 52-53; idem, Korczyński Michat, [w:] EK, t. 9, Lublin 2002, kol. 836-837; W. Sarna, Dzieje diecezji przemyskiej obrzadku łac[ińskiego]. Episkopat przemyski o[brządku] t[acińskiego], cz. 2, Przemyśl 1910, s. 527-532; T. Śliwa, Korczyński Michał Tomasz Wincenty, [w:] SPTK, t. 2, red. H. E. Wyczawski, Warszawa 1982, s. 352-355; idem, Michat Tomasz Wincenty Korczyński, [w:] Arcybiskupi i biskupi przemyscy, s. 190-196.

${ }^{52}$ J. Kwolek, Archiwa diecezji przemyskiej, s. 16.

${ }^{53}$ Archiwa Kościoła katolickiego w Polsce, s. 83-84.

${ }^{54}$ Andrzej Urban - kapelan biskupi, kanclerz konsystorza w latach 1838-1840, a następnie proboszcz w Łące, gdzie zmarł w 1847 r. Zob. J. Kwolek, Archiwa diecezji przemyskiej, s. 17.

${ }^{55}$ J. Patryn, op. cit., s. 28.

${ }^{56}$ Franciszek Ksawery Zachariasiewicz - urodził się 1 XII 1770 r. w rodzinie ormiańskiej w Stanisławowie, gdzie ukończył gimnazjum. Od 1789 r. studiował na Wydziale Teologicznym Uniwersytetu we Lwowie, a 9 VIII 1795 r. otrzymał święcenia kapłańskie z rąk arcybiskupa lwowskiego obrządku ormiańskiego. Pełnił funkcję wikariusza w katedrze ormiańskiej, w 1797 r. uzyskał na Uniwersytecie we Lwowie doktorat z teologii i rozpoczął wykłady z historii Kościoła, a z czasem również z prawa kanonicznego. W 1802 r. został profesorem zwyczajnym, w latach 1826-1827 był rektorem uniwersytetu. Jeszcze w 1812 r. przeszedł na obrządek łaciński, pełniąc w archidiecezji lwowskiej liczne funkcje. W latach 1836-1840 był biskupem tarnowskim, a od 1840 r. przemyskim. Zmarł 12 VI 1845 r. w Przemyślu i został pochowany na tamtejszym cmentarzu. Zob. K. Gabriel, Zachariasiewicz Franciszek (1770-1845), [w:] SPTK, t. 4, Warszawa 1983, s. 496-498; P. Nitecki, Biskupi Kościoła w Polsce w latach 965-1999. Stownik biograficzny, wyd. 2, Warszawa 2000, kol. 503; B. Walicki, Franciszek Ksawery Zachariasiewicz, [w:] Arcybiskupi i biskupi przemyscy, s. 197-198; S. Zych, Zachariasiewicz Franciszek Ksawery, [w:] EK, t. 20, Lublin 2014, kol. 115. 
rządców parafii do spisywania ich dziejów ${ }^{57}$. Podjęty trud wymienionych biskupów zaowocował pracami historycznymi ks. Franciszka Pawłowskiego ${ }^{58}$, który sam archiwum nie porządkował, ale dzięki cytowaniu znajdujących się w nim dokumentów zainteresował nim licznych badaczy ${ }^{59}$.

Zdecydowanie najlepszy okres dla przemyskich archiwaliów kościelnych nastał, gdy bp J. S. Pelczar ${ }^{60}$ mianował ks. J. Kwolka archiwariuszem kurialnym ${ }^{61}$. Obejmując tę funkcję, przemyski kanonista chciał doprowadzić do erygowania archiwum diecezjalnego jako dobrze zorganizowanej instytucji o charakterze naukowym, ale droga do tego była jeszcze daleka. Przede wszystkim w miarę możliwości należało zebrać rozproszone archiwalia i uporządkować je. Kolejnym krokiem była troska o odpowiednią siedzibę i uregulowanie zasad prawnych. Najprawdopodobniej, przystępując do porządkowania zasobów, ks. J. Kwolek korzystał ze wskazań Kodeksu Prawa Kanonicznego z 1917 r. ${ }^{62}$ oraz instrukcji papieża Piusa XI do biskupów włoskich $O$ ochronie, urządzeniu i używaniu archiwów i bibliotek kościelnych ${ }^{63}$. Prace te szerzej zostaną omówione w dalszej

${ }^{57}$ J. Kwolek, Archiwa diecezji przemyskiej, s. 17-18.

${ }^{58}$ Franciszek Pawłowski - urodził się 3 XII 1807 r. w Leżajsku jako syn Jana (asesora, skarbnika i burmistrza Leżajska) oraz Magdaleny z Łęckich. W 1825 r. ukończył Gimnazjum w Rzeszowie. W latach 1827-1831 studiował teologię w Wiedniu, a w 1831 r. przyjął święcenia kapłańskie w Przemyślu z rąk bpa Jana Potoczki, którego został kapelanem i sekretarzem. W 1832 r. był administratorem parafii Wysoka Łańcucka. Od 1833 r. związany z przemyskim Seminarium Duchownym, gdzie pełnił funkcję wykładowcy Pisma Świętego, prefekta studiów, rektora i wicerektora. Sprawował też odpowiedzialne funkcje w konsystorzu biskupim. W $1845 \mathrm{r}$. został kanonikiem honorowym, a w 1850 gremialnym kapituły katedralnej. Od 1854 r. był w niej scholastykiem. W 1872 r. otrzymał godność papieskiego prałata domowego. Był też członkiem Akademii Umiejętności w Krakowie. Zmarł 26 VII 1876 r. w Przemyślu i został pochowany na tamtejszym cmentarzu. Zob. D. Bialic, Pawłowski Franciszek Ksawery, [w:] PSB, t. 25, Wrocław 1980, s. 497-498; F. Pawłowski, Prałaci i kanonicy Kapituły Katedralnej obrzadku łacińskiego w Przemyślu, przekład Z. Trojnar, Przemyśl 2018, s. 207.

${ }^{59}$ J. Kwolek, Archiwum Diecezjalne przy Kurii Biskupiej, s. 516.

${ }^{60}$ Józef Sebastian Pelczar - urodził się 17 I 1842 r. w Korczynie k. Krosna. W 1850 r. rozpoczą naukę w rzeszowskiej szkole głównej, a następnie kontynuował ją w przemyskim gimnazjum. W 1860 r. wstąpił do Seminarium Duchownego w Przemyślu, a 17 VII 1864 r. przyjął święcenia kapłańskie. Po nich pracował jako wikariusz w Samborze, a następnie wyjechał do Rzymu, gdzie uzyskał doktoraty z teologii i prawa kanonicznego. Po powrocie do diecezji został wikariuszem w Wojutyczach, później w Samborze, a następnie objął funkcję prefekta i wykładowcy w seminarium przemyskim. Od 1877 r. był profesorem zwyczajnym historii kościelnej i prawa kanonicznego na Wydziale Teologicznym Uniwersytetu Jagiellońskiego w Krakowie, a w roku akademickim 1882/83 był rektorem tej uczelni. W 1899 r. został sufraganem przemyskim, a w roku następnym ordynariuszem. Zmarł 28 III 1924 r. w Przemyślu. Dnia 2 VI 1991 r. został beatyfikowany w Rzeszowie przez Jana Pawła II, a 18 V 2003 r. ten sam papież kanonizował go w Rzymie. Zob. S. Krzywiński, Działalność duszpasterska Józefa Sebastiana Pelczara biskupa przemyskiego w latach 1899-1924, Przemyśl 2003, passim; T. Śliwa, Pelczar Józef Sebastian, [w:] PSB, t. 25, Wrocław 1980, s. 547-550; idem, Józef Sebastian Pelczar, w: Arcybiskupi i biskupi przemyscy, s. 212-225; H. E. Wyczawski, Pelczar Józef Sebastian, [w:] SPTK, t. 3, red. H. E. Wyczawski, Warszawa 1982, s. 336-345.

${ }^{61}$ Archiwa Kościoła katolickiego w Polsce, s. 84.

${ }^{62}$ Codex Iuris Canonici, Romae 1917, kan. 375 par. 1; kan. 376 par. 2.

${ }^{63}$ Lettera circolare di Sua Eminenza Rev. Il. Sig. Cardinale Gaspari ai Vescovi d' Italia per la conservazione, custodia ed uso degli Archivi e delle Biblioteche ecclessiastiche, Roma 1923. 
części artykułu, niemniej już teraz należy nadmienić, że przy pomocy kleryków przemyskiego seminarium zasadniczy trzon działań został zakończony w roku $1924^{64}$. Ważnym momentem dla funkcjonowania archiwum było przydzielenie na jego potrzeby przez bpa Anatola Nowaka ${ }^{65}$ dwóch pomieszczeń w gruntownie przebudowanym budynku kurii, gdzie w 1926 r. przeniesiono zasoby. Nowa siedziba zaopatrzona została w oświetlenie elektryczne, odpowiednie dla tej instytucji meble i sprzęt oraz właściwe zabezpieczenie przed wilgocią, pożarem i kradzieżą ${ }^{66}$.

Na początku 1927 r. ks. J. Kwolek, chcąc umieścić przemyskie archiwum w odpowiednich ramach prawnych, rozpoczął pracę nad przygotowaniem dla niego statutu i regulaminu. W tym celu posiłkował się wspominaną już instrukcją papieża Piusa XI do biskupów włoskich z 15 kwietnia 1923 r., Kodeksem Prawa Kanonicznego oraz zasadami obowiązującymi w archiwach państwowych ${ }^{67}$. Dzięki temu powstał dokument zatytułowany Statut organizacyjny Archiwum diecezjalnego przy Kurii Biskupiej o. ł. w Przemyślu, składający się z 20 artykułów. W pierwszym z nich została podkreślona odrębność instytucji kościelnej o nazwie Archiwum diecezjalne, kierującej się własnymi ustawami. W artykule drugim zwrócono uwagę, że jej celem jest nie tylko gromadzenie archiwaliów, lecz również ich udostępnianie. W dalszej części statutu (art. III i IV) określono rodzaje dokumentów, które mogły być do archiwum przyjmowane oraz zaznaczono (art. V), że ,na wszelkie przyjęte do archiwum rękopisy i zabytki wystawia archiwariusz do rąk składającego poświadczenie odbioru”. Szereg artykułów (VI-XVII) precyzowało prawa, obowiązki i zadania urzędnika kurialnego odpowiedzialnego za archiwum, którego tytułowano mianem „dyrektora archiwum diecezjalnego” lub „archiwariusza”. Artykuł XVIII regulował wewnętrzną strukturę archiwum, a XIX nakazywał zaopatrywanie dokumentów w nim przechowywanych w pieczęcie i sygnatury. Ostatni (XX) polecał z kolei tej instytucji gromadzenie urzędowych wydawnictw diecezjalnych (schematyzmy, kroniki itp.), publikacji dotyczących historii diecezji i wszelkiej literatury pomocniczej związanej z pracą naukową w tej dyscyplinie ${ }^{68}$.

\footnotetext{
${ }^{64}$ J. Patryn, op. cit., s. 33.

${ }^{65}$ Anatol Nowak - urodził się 12 X 1862 r. w Kańczudze. Uczęszczał do gimnazjum w Rzeszowie, a następnie w Przemyślu, gdzie w 1881 r. zdał egzamin dojrzałości. Po nim studiował teologię na Uniwersytecie Jagiellońskim w Krakowie i 15 VII 1885 r. przyjął święcenia kapłańskie. Pracował jako wikariusz w Bolechowicach i Podgórzu, a następnie pełnił funkcję notariusza, sekretarza i w końcu kanclerza konsystorza biskupiego. Dnia 30 XII 1900 r. otrzymał konsekrację biskupią i został sufraganem krakowskim. W 1924 r. został mianowany biskupem przemyskim. Zmarł w Przemyślu 5 IV 1933 r. Zob. J. Kwolek, Śp. Anatol Nowak. Ordynariusz przemyski o. ł., KDP 1933, R. 33, z. 4, s. 165-167; H. Borcz, Nowak Anatol, [w:] EK, t. 14, red. E. Gigilewicz, Lublin 2010, kol. 30-31; T. Śliwa, Anatol Nowak, [w:] Arcybiskupi i biskupi przemyscy, s. 225-230.

${ }^{66}$ J. Kwolek, Archiwa diecezji przemyskiej, s. 26; idem, Archiwum diecezjalne, s. 516.

${ }^{67}$ J. Patryn, op. cit., s. 34-35.

${ }^{68}$ Statut organizacyjny Archiwum diecezjalnego przy Kurii Biskupiej o. t. w Przemyślu, [w:] J. Kwolek, Archiwa diecezji przemyskiej, s. 61-64.
} 
Oprócz statutu ks. J. Kwolek opracował również piętnastopunktowy Regulamin pracowni Archiwum diecezjalnego przy Kurii Biskupiej o. t. w Przemyślu. $\mathrm{W}$ pierwszym punkcie podkreślał, że pierwszeństwo w korzystaniu ze zbiorów mają urzędnicy władzy diecezjalnej i odpowiednich jej agend, deponujących $\mathrm{w}$ archiwum swoją dokumentację. Zwracano uwagę, że zasadniczo powinni to czynić na miejscu, a jedynie w nadzwyczajnych sytuacjach po odpowiedniej adnotacji można było archiwalia na krótki czas wypożyczyć. W punktach 2-8 autor regulaminu określał kryteria umożliwiające udostępnianie zasobów archiwum innym osobom i instytucjom, podkreślając przede wszystkim zasady korzystania z nich oraz sporządzania kopii lub reprodukcji. Warto tu zacytować punkt 7, który brzmiał następująco: „Przed przystąpieniem do osobistej pracy w archiwum, otrzymuje każdy pracownik do odczytania regulamin pracowni archiwalnej i zobowiązuje się podpisem do jego przestrzegania”. Punkt 9 odnosił się z kolei do tak popularnej dziś zasady o ochronie danych osobowych, informując, że „księgi i akta z ostatnich lat 50 mogą być udzielane do badań osobom zaufanym tylko za osobnem pozwoleniem Ordynariusza". Punkty 10-14 regulaminu miały na celu ochronę udostępnianych zbiorów przed zniszczeniem, zagubieniem i kradzieżą, przy czym najbardziej wymowne stwierdzenie jasno precyzowało, iż „Archiwaljów nie wypożycza się do domu, i w ogóle nie wolno ich wynosić poza obręb archiwum, względnie Kurji Biskupiej bez pozwolenia Ordynariusza". W końcu zastrzegano sobie również prawo do przekazania archiwum egzemplarza publikacji opartej przynajmniej częściowo na jego zasobach, jak również egzemplarza wykonanych fotografii czy innych form reprodukcji (pkt 15) ${ }^{69}$.

Dzięki tym pracom 15 października 1927 r. bp A. Nowak erygował archiwum diecezjalne, zatwierdził jego statut i regulamin ${ }^{70}$, a pięć dni później mianował ks. J. Kwolka dyrektorem tej instytucji ${ }^{71}$. Wówczas też w myśl zatwierdzonego statutu nowy dyrektor rozpoczął prowadzenie ksiąg urzędowych: dziennika podawczego, księgi korzystających, księgi przybytków, księgi rachunkowej i kroniki archiwum ${ }^{72}$.

\section{Praca ks. J. Kwolka w Archiwum Diecezjalnym i jego troska o zabez- pieczanie archiwaliów w Polsce}

Dla przemyskiego archiwisty fakt erygowania nowej instytucji stanowił milowy krok do uporządkowania diecezjalnych zasobów i był ukoronowaniem pewnego etapu jego wysiłków i starań. Nie oznaczało to jednak zaprzestania przez niego dalszej pracy. Obecnie, gdy już zaznajomiliśmy się z podstawami jego działalności

${ }^{69}$ Regulamin pracowni Archiwum diecezjalnego przy Kurii Biskupiej o. t. w Przemyślu, [w:] J. Kwolek, Archiwa diecezji przemyskiej, s. 65-68.

${ }^{70}$ J. Patryn, op. cit., s. 42.

${ }^{71}$ AAPrz, APK TP ks. Kwolek Jan, Pismo bpa Anatola Nowaka do ks. Jana Kwolka z 20 X 1927 r.

${ }^{72}$ Archiwum Diecezjalne Przemyskie w latach 1927 i 1928. (Sprawozdanie archiwisty), KDP 1929, R. 29, z. 3-4 (dalej: Sprawozdanie 1927 i 1928), s. 67. 
archiwalnej, pora ukazać jej szczegóły, które zostaną podane w następujących punktach:

1. Zebranie rozproszonych archiwaliów.

2. Porządkowanie archiwaliów.

3. Troska o bazę lokalową archiwum i bibliotekę podręczną.

4. Udostępnianie archiwaliów.

5. Udział w opracowaniu naukowych podstaw archiwistyki oraz troska o zabezpieczenie zbiorów kościelnych w Polsce.

\section{Zebranie rozproszonych archiwaliów}

Już w 1918 r., obejmując pieczę nad archiwum kurialnym, ks. J. Kwolek rozpoczął równocześnie starania nad pozyskiwaniem do niego dokumentów rozproszonych w parafiach diecezji. Przynosiło to jednakże mizerne skutki, gdyż do 1926 r. wpłynęło do niego zaledwie $17 \mathrm{ksiąg}^{73}$. W tej sytuacji, prawdopodobnie z inicjatywy powołanego dyrektora, w 1927 r. bp A. Nowak wydał rozporządzenie, w którym wzywał rządców parafii, by do archiwum przesyłali „stare dokumenty, księgi i akta, jakie znajdują się na plebanji lub w kościele, a do urzędowania w kancelarji parafjalnej nie są już potrzebne". Rozporządzeniu podlegały wszelkie dokumenty pergaminowe i papierowe, metryki, wizytacje, rachunki kwerendy, akta grodzkie i ziemskie itp. sprzed roku 1772. W dalszej jego części informowano proboszczów, że przesłanie ich pozwoli na fachową konserwację, a przede wszystkim na zabezpieczenie przed zniszczeniem, przy czym miały być one traktowane jako depozyt, z którego właściciele będą mogli skorzystać w pierwszej kolejności. W zarządzeniu obligowano również księży dziekanów do zwracania uwagi na archiwa parafialne $\mathrm{w}$ trakcie wizytacji i nakazania księżom odsyłania do kurii dokumentów wymienionych w dekrecie ${ }^{74}$. Dzięki tej stanowczej interwencji przemyskich władz diecezjalnych tylko w latach 1927-1928 archiwum wzbogaciło się o 933 księgi pozyskane z parafii oraz 62 pergaminy $^{75}$. Ogłoszenie o podobnej treści zostało opublikowane również w KDP z 1929 r. ${ }^{76}$ Poza tym w sprawozdaniach archiwalnych drukowanych w KDP ks. J. Kwolek początkowo podawał ogólnie liczbę parafii, które nie oddały starych archiwaliów, a zdarzało się nawet, że wymieniał je wprost ${ }^{77}$. Swoje wysiłki i sukcesy w tym względzie

\footnotetext{
${ }^{73}$ Sprawozdanie 1927 i 1928, s. 69.

${ }^{74}$ Rozporządzenie w sprawie archiwów, KDP 1927, R. 27, z. 2, s. 57-58.

${ }^{75}$ Sprawozdanie 1927 i 1928, s. 69, 71.

${ }^{76}$ Przypomnienie o odsyłaniu archiwaliów, KDP 1929, R. 29, z. 3-4, s. 59.

${ }^{77}$ Sprawozdanie 1927 i 1928, s. 70; Archiwum Diecezjalne Przemyskie w roku 1929. (Sprawozdanie archiwisty), KDP 1930, R. 30, z. 1 (dalej: Sprawozdanie 1929), s. 60; Archiwum Diecezjalne Przemyskie w roku 1931. (Sprawozdanie archiwisty), KDP 1932, R. 32, z. 1 (dalej: Sprawozdanie 1931), s. 32; Archiwum Diecezjalne Przemyskie. Sprawozdanie za rok 1932, KDP 1933, R. 33, z. 1 (dalej: Sprawozdanie 1932), s. 22; Archiwum Diecezjalne Przemyskie. Sprawozdanie za rok 1933, KDP 1934, R. 34, z. 3 (dalej: Sprawozdanie 1933) s. 82; Archiwum Diecezjalne Przemyskie. Sprawozdanie za rok 1934, KDP 1935, R. 35, z. 5-6 (dalej: Sprawozdanie 1934), s. 95.
} 
referował w listach do ks. Jana Fijałka ${ }^{78}$. W marcu 1930 r. pisał: „Do archiwum wskutek ostatniego sprawozdania i nowych ponagleń proboszczów dostaję jeszcze dużo pięknych rzeczy. Są i pergaminy, jeden z 1409 r., jeden niby z XIV w. ale falsyfikat z końca XVIII w. (mam już takich cztery, wszystko zdaje się z tej ręki co jeden przechowywany w zbiorach Akademii Umiejętności rzekomo z r. 1297 24 listop. dla Polnej, w katal. Czubka pod nr. 3). Między innymi dostałem cenną księgę sądową wsi Futoma obejmującą lata 1446-1664. Dusza się raduje tylko ciało mdłe" ${ }^{\text {. W }}$. innym miejscu stwierdzał: „Dużo miałbym do opowiadania jak wyratowałem od proboszczów opornych archiwalia, od jednych prośbą, od innych groźbą, w kilku wypadkach proboszcz przynosił księgi, gdy mu groził jakiś proces kanoniczny, tu i ówdzie trzeba było szpiegowskiego użyć podstępu aby dowiedzieć się co tam jest $\mathrm{w}$ danem archiwum parafialnem (...). Teraz troskam się i wysilam fantazję jakby tu podejść czy zastraszyć onych ok. 20 najoporniejszych. Tu i ówdzie nie pomoże pisanie, trzeba będzie być osobiście"80. Dzięki aktywności przemyskiego archiwisty do 1937 r. udało się z parafii uzyskać sporo ksiąg i pergaminów, co dokładniej ukazuje tabela nr 1 .

Tabela 1. Księgi i pergaminy pozyskane do archiwum z parafii diecezji przemyskiej w latach 1927-1936

\begin{tabular}{|c|c|c|}
\hline Rok & Liczba pozyskanych ksiąg & Liczba pozyskanych pergaminów \\
\hline 1927 & 356 & - \\
\hline 1928 & 577 & $62^{*}$ \\
\hline 1929 & 98 & 4 \\
\hline 1930 & 87 & 9 \\
\hline 1931 & 56 & 10 \\
\hline 1932 & $22^{* *}$ & 9 \\
\hline 1933 & 40 & 20 \\
\hline 1934 & 2 & 1 \\
\hline
\end{tabular}

${ }^{78}$ Jan Fijałek - urodził się 8 V 1864 r. w Pogwizdowie k. Bochni. W latach 1883-1884 studiował w Seminarium Duchownym w Tarnowie, a następnie w latach 1884-1887 na wydziale UJ w Krakowie. Jako alumn diecezji krakowskiej przyjął w 1887 r. święcenia kapłańskie. W Rzymie uzyskał dyplom paleografa-archiwisty Stolicy Apostolskiej i doktorat z prawa kanonicznego na Lateraneum. Po powrocie pełnił funkcję penitencjarza w kościele NMP w Krakowie i katechety szkół średnich. W 1891 r. na UJ obronił doktorat z teologii i rozpoczął wykłady z historii Kościoła, a w 1893 r. uzyskał habilitację. W latach 1896-1912 kierował katedrą historii Kościoła na UJK we Lwowie, a następnie pracował na UJ, gdzie w 1919 r. utworzył i kierował katedrą historii Kościoła w Polsce. W 1919 r. został czynnym członkiem Polskiej Akademii Umiejętności, a w 1927 r. dyrektorem jej wydziału historyczno-filozoficznego. Zmarł 19 X 1936 r. w Krakowie. Zob. P. Pałka, Fijałek Jan, [w:] EK, t. 5, Lublin 1989, kol. 178-180; W. Semkowicz, Fijatek Jan Nepomucen, [w:] PSB, t. 6, Kraków 1948, s. 441-443; J. Kracik, Fijałek Jan Nepomucen, [w:] SPTK, t. 5, red. L. Grzebień, Warszawa 1983, s. 374-383.

${ }^{79}$ Biblioteka Naukowa PAU i PAN w Krakowie, sygn. 4685, Korespondencja Jana Kwolka z Janem Fijałkiem, List ks. Jana Kwolka do ks. Jana Fijałka z dnia 11 III 1930 r.

${ }^{80}$ Ibidem, List ks. Jana Kwolka do ks. Jana Fijałka z 4 II 1931 r. 


\begin{tabular}{|c|c|c|}
\hline 1935 & 14 & - \\
\hline 1936 & 30 & 19 \\
\hline Razem & $\mathbf{1 2 8 2}$ & $\mathbf{1 3 4}$ \\
\hline
\end{tabular}

Źródło: Sprawozdanie 1927 i 1928, s. 69,71; Sprawozdanie 1929, s. 60; Archiwum Diecezjalne Przemyskie w roku 1930 (Sprawozdanie archiwisty), KDP 1931, R. 31, z. 1, (dalej: Sprawozdanie 1930), s. 48; Sprawozdanie 1931, s. 31-32; Sprawozdanie 1932, s. 21; Sprawozdanie 1933, s. 81-82; Sprawozdanie 1934, s. 95; Archiwum Diecezjalne Przemyskie. Sprawozdanie za rok 1935, KDP 1936, R. 36, z. 6, (dalej: Sprawozdanie 1935), s. 201; Archiwum Diecezjalne Przemyskie. Sprawozdanie za rok 1936, KDP 1937, R. 37, z. 2-4, (dalej: Sprawozdanie 1936), s. 114.

*dane ukazują łączną liczbę pergaminów pozyskanych w latach 1927-1928

**dane zawierają kilka ksiąg pozyskanych od osób prywatnych

Tabela ukazuje ilość ksiąg i pergaminów pozyskanych w latach 1927-1936 do archiwum z parafii diecezji przemyskiej. Łącznie były to 1282 księgi i 134 pergaminy. Najwięcej archiwaliów udało się uzyskać w latach 1927-1928, co niewątpliwie było wynikiem rozporządzenia bpa A. Nowaka z 1927 r., nakazującego rządcom parafii deponowanie ich w kurii. Od opornych na zalecenia władz kościelnych kapłanów uzyskano stare dokumenty w sporej liczbie w 1933 r., co prawdopodobnie było związane z objęciem przez ks. J. Kwolka urzędu kanclerza i możliwości wywierania większego nacisku. Jak zaznaczono, pewne podane w tabeli dane są nieprecyzyjne. Mianowicie ilość pozyskanych 62 pergaminów dotyczy lat 1927-1928, jednakże trudno jednoznacznie ocenić, ile z nich wzbogaciło zasoby w poszczególnych latach, natomiast spośród 22 ksiąg pozyskanych w roku 1932 kilka (zdecydowana mniejszość) pochodziło od osób prywatnych.

Ksiądz J. Kwolek starał się pozyskiwać przemyskie archiwalia nie tylko z parafii, ale również z instytucji kościelnych i świeckich oraz od osób prywatnych. W sprawozdaniu za rok 1927 i 1928 informował on, że powiodła się rewindykacja starych akt z Muzeum Diecezjalnego w Tarnowie, jak i z Seminarium Duchownego w Przemyślu ${ }^{81}$. Z kolei w 1931 r. udało mu się z „Ossolineum” odzyskać Księge Bractwa Kapłańskiego Ziemi Sanockiej ${ }^{82}$, a w 1933 r. z rąk prywatnych otrzymał 10 listów bpa J. S. Pelczara ${ }^{83}$. Innym źródłem pozyskiwania przemyskich archiwaliów był ich zakup w antykwariatach. Jak podawał dyrektor w sprawozdaniu za rok 1932, u antykwariusza wykupiono kilkaset aktów dotyczących 46 parafii, przeznaczając na ten cel 177 zł, zaś w 1933 r. była to już kwota 370 zł i 50 gr. Łącznie tylko w ciągu tych dwóch lat tą drogą trafiło do archiwum przemyskiego około 1050 luźnych aktów ${ }^{84}$. W grudniu 1932 r. tak o tym pisał do ks. J. Fijałka: „Wykupuję teraz nasze diecezjalne archiwalia (akta parafialne w wielkiej ilości,

${ }^{81}$ Sprawozdanie 1927 i 1928 , s. 70.

${ }^{82}$ Polska Akademia Umiejętności Biblioteka Naukowa PAU i PAN w Krakowie, sygn. 4685, Korespondencja Jana Kwolka z Janem Fijałkiem, List ks. Jana Kwolka do ks. Jana Fijałka z dnia 14 V $1931 \mathrm{r}$.

${ }^{83}$ Sprawozdanie 1933, s. 82.

${ }^{84}$ Sprawozdanie 1932, s. 22, 25; Sprawozdanie 1933, s. 82, 85. 
kilka ksiąg i pergaminów jeden z r. 1400) od antykwarza lwowskiego Tomasika, który wielki ich zbiór ma z (...) partyj archiwum państwowego. Mam już tego całe duże pudło. W ten sposób choć częściowo odzyska diecezja rzeczy stracone w epoce józefińskiej. Przeważają stare akta grodzkie i innych instytucyj cywilnych, mniej wartościowe. Płacę przeciętnie $1 / 2$ złotego za jeden akt" ${ }^{\prime 85}$. Dzięki tej działalności ks. J. Kwolka na początku 1937 r., gdy w zasadzie koncentracja archiwaliów została zakończona, było ogółem w archiwum diecezjalnym 2074 księgi i 266 pergaminów ${ }^{86}$. Akcja ta zaowocowała również pozyskaniem znajdujących się w zasobach parafialnych ksiąg wiejskich, które archiwariusz był skłonny wymienić z instytucjami państwowymi na dokumenty kościelne ${ }^{87}$.

Ksiądz J. Kwolek troszczył się nie tylko o sprowadzenie do archiwum rozproszonych ksiąg i pergaminów, lecz podjął również starania, by proboszczowie regularnie przesyłali odpisy ksiąg metrykalnych. W diecezji przemyskiej pierwsze rozporządzenie dotyczące tej kwestii wydał w formie okólnika z 21 września 1826 r. bp Jan Antoni Potoczki $^{88}$, a brzmiało ono następująco: „Pragnąc jak najlepiej zabezpieczyć księgi metrykalne oraz ułatwić uzyskanie ich odpisu urzędowego w razie ich zaguby lub spalenia, zobowiązujemy wszystkich duszpasterzy, aby odtąd, tak za rok bieżący, jak i na przyszłość co roku pod koniec stycznia, z każdego kościoła parafialnego macierzystego albo z filialnego czyli kapelanji miejscowej, wierne wypisy (extractus) z całego roku urodzonych, zaślubionych i zmarłych z ksiąg metrykalnych wiernie i dosłownie sporządzone, podpisane i pieczęcią kościelną zaopatrzone, wreszcie przez dziekana właściwego co do dosłownej zgodności z oryginałem potwierdzone, do konsystorza Naszego niezawodnie nadsyłali, celem ich przechowania w archiwum kancelarii" ${ }^{89}$.

Od tej pory rządcy parafii przesyłali do konsystorza kopie ksiąg metrykalnych (chrztów, ślubów, pogrzebów), dzięki czemu powstał w nim specjalny dział

${ }^{85}$ Polska Akademia Umiejętności Biblioteka Naukowa PAU i PAN w Krakowie, sygn. 4685, Korespondencja Jana Kwolka z Janem Fijałkiem, List ks. Jana Kwolka do ks. Jana Fijałka z dnia 20 XII $1932 \mathrm{r}$.

${ }^{86}$ Sprawozdanie 1936, s. 114

${ }^{87}$ J. Patryn, op. cit., s. 79.

${ }^{88}$ Jan Antoni Potoczki (Potocki) - urodził się 27 XII 1759 r. w Basfalof w Siedmiogrodzie w rodzinie ormiańskiej. Studiował w papieskim Kolegium dla Unickich Ormian i Ukraińców we Lwowie, ale po jego likwidacji przeniósł się do Seminarium Generalnego obrządku łacińskiego w tym mieście i ukończył teologię na Uniwersytecie Lwowskim. W 1785 r. uzyskał doktorat z teologii. 12 VIII 1786 r. otrzymał święcenia w obrządku ormiańskim. Pracował na Uniwersytecie Lwowskim. W 1796 r. przeszedł na obrządek łaciński obejmując parafię Żydaczów w diecezji lwowskiej, był też dziekanem stryjskim i honorowym kanonikiem kapituły lwowskiej obrządku łacińskiego. W $1823 \mathrm{r}$. został proboszczem w Stanisławowie, a 4 II 1825 r. cesarz mianował go biskupem przemyskim. Jego konsekracja miała miejsce w katedrze lwowskiej 12 III 1826 r., a tydzień później odbył ingres do katedry przemyskiej. Zmarł 16 V 1832 r. w Przemyślu i został pochowany w krypcie tamtejszej katedry. Zob. B. Kumor, Potoczki Antoni Jan, [w:] SPTK, t. 3, red. H. E. Wyczawski, Warszawa 1982, s. 429-430; P. Nitecki, op. cit., s. 358-359; T. Śliwa, Jan Antoni Potoczki (Potocki), [w:] Arcybiskupi i biskupi przemyscy, s. 188-189; S. Zych, Potoczki Jan Antoni bp, [w:] EK, t. 16, red. E. Gigilewicz, Lublin 2012, kol. 117.

${ }^{89}$ Cyt. za: J. Kwolek, Ekstrakty metrykalne w Archiwum Diecezjalnem Przemyskiem, KDP 1928, R. 28 , z. 10-11, s. 235-236. 
Ekstrakty metrykalne, do którego również w latach 1849-1891 przekazywano odpisy ksiąg zapowiedzi ${ }^{90}$. Biskup J. S. Pelczar na ten obowiązek proboszczów zwrócił uwagę w Synodzie z 1902 r. ${ }^{91}$, jednakże nie był on przez władze diecezjalne egzekwowany, prawdopodobnie przez brak miejsca na odpisy metryk, co spowodowało, że statut synodalny stał się martwą literą ${ }^{92}$. W tej sytuacji ks. J. Kwolek w KDP z 1928 r. opublikował artykuł Ekstrakty metrykalne w Archiwum Diecezjalnem Przemyskiem, w którym oprócz rysu historycznego tej kwestii i opisu sposobu przechowywania kopii metryk (co miało wzbudzić zaufanie księży proboszczów), przede wszystkim umieścił spis parafii wraz z wykazem ekstraktów metrykalnych przekazanych władzom diecezjalnym ${ }^{93}$. W tym samym zeszycie KDP znalazło się rozporządzenie bpa A. Nowaka, w którym przypomniano przepisy kościelne i państwowe dotyczące ekstraktów metrykalnych, polecając wraz z wykazami chrztów, ślubów i pogrzebów przesyłać również odpisy z księgi bierzmowanych. Równocześnie polecano księżom dziekanom odbierać rokrocznie odpisy od podległych sobie rządców parafii, którym przypominano także o uzupełnieniu zaległości ${ }^{94}$. Rok później władze diecezjalne ponowiły apel w sprawie odsyłania ekstraktów metrykalnych ${ }^{95}$. Dzięki tym działaniom, jak w sprawozdaniu archiwalnym za rok 1929 informował dyrektor, nastąpił ,znaczny przyrost ekstraktów metrykalnych” oraz uzupełnianie braków ${ }^{96}$, jednakże dwa lata później ubolewał nad istniejącymi jeszcze w tej materii sporymi zaniedbaniami, których przyczyn upatrywał w zaniechaniach ze strony kuriii ${ }^{97}$. Co pewien czas zarządzenie o przekazywaniu duplikatów metrykalnych było powtarzane, między innymi w KDP z 1948 r. ${ }^{98}$

Jak łatwo zauważyć, zdecydowana postawa ks. J. Kwolka w kwestii restytucji archiwaliów oraz przesyłania ekstraktów metrykalnych sprawiła, że kierowana przez niego instytucja w ciągu kilku lat powiększyła swoje zbiory. Niestety, wybuch II wojny światowej i jej konsekwencje polityczne sprawiły nie tylko wstrzymanie tych prac, lecz również spowodowały utratę znacznej części zasobów. Władze sowieckie - pod zwierzchnością których znalazła się prawostronna część Przemyśla - w 1940 r. upaństwowiły archiwum diecezjalne, a 25 listopada 1940 r. NKWD przejęło 2086 ksiąg i 248 pergaminów, jak również inwentarz kartkowy ${ }^{99}$. Trzy

${ }^{90}$ Ibidem, s. 236.

${ }^{91}$ Acta et Statuta Synodi dioecesanae Premisliensis quam A. D. 1902, Diebus 19, 20, 21, 22 mensis habuit Josephus Sebastianus Pelczar Episcopus Premisliensis Latinorum [...], Premisliae 1903 , statut 439.

${ }^{92}$ J. Kwolek, Ekstrakty metrykalne, s. 236-237.

${ }^{93}$ Ibidem, s. 231-249.

${ }^{94}$ Rozporzadzenie o ekstraktach metrykalnych, KDP 1928, R. 28, z. 10-11, s. 222-223.

${ }^{95}$ Przypomnienie o ekstraktach metrykalnych, KDP 1929, R. 29, z. 3-4, s. 58.

${ }^{96}$ Sprawozdanie 1929, s. 60.

${ }^{97}$ Sprawozdanie 1931, s. 32.

${ }_{98}^{98}$ Księgi metrykalne, KDP 1948, R. 41, z. 2-3, s. 44.

${ }^{99}$ AAPrz, Teczka „Archiwum. Zabranie i starania o zwrot”, b. sygn., Protokół przejęcia zasobu Archiwum Diecezjalnego w Przemyślu z dnia 25 XI 1940 r., b. s. 
dni później zasób wywieziono do Lwowa, gdzie prawdopodobnie był przetrzymywany w ratuszu, zaś po wkroczeniu do tego miasta Niemców przewieziono go na ul. Podwale 13 (budynek dawnego Archiwum Państwowego) ${ }^{100}$. Dodać należy, że ks. J. Kwolek z pewnością mocno przeżywał całą tę sytuację, o czym może świadczyć pośmiertne wspomnienie zamieszczone w KDP przez ks. Stefana Momidłowskiego ${ }^{101}$, dotyczące wprawdzie nie archiwaliów, lecz biblioteki kapitulnej: „Zmarły dowiedział się, jak jeden z najeźdźców mieszkając w domu, w którym była umieszczona niedawno wspaniała skatalogowana biblioteka kapitulna przez jedną zimę opalał swe mieszkanie książkami z tej biblioteki, płonęły dzieła, niektóre «białe kruki», mapy, atlasy z XVI wieku itd. Zastałem raz śp. ks. Kwolka - a mieszkaliśmy razem - jak płakał, tak bolał nad niszczeniem dzieł polskiej kultury: zobaczyłem, że dla uspokojenia czytał księgę Joba"102.

W 1942 r. ks. J. Kwolek rozpoczął u władz niemieckich starania o odzyskanie przemyskich archiwaliów ${ }^{103}$. Udało się to dopiero 5 czerwca 1943 r., gdy ks. Hieronim Kocyłowski ${ }^{104}$, posiadając pełnomocnictwa od dyrektora archiwum, odebrał je we Lwowie, jednakże władze okupacyjne nie oddały 810 tomów ksiąg metrykalnych i 30 tomów innych ksiąg uznanych przez nie za dokumenty świeckie ${ }^{105}$. Dodatkowo zginęło siedem ksiąg, jednakże z czasem cztery z nich się odnalazły. Dyrektor przemyskiego archiwum rozpoczął starania o odzyskanie pozostałych archiwaliów, jednakże w 1944 r. Niemcy wywieźli je w kierunku Dolnego Śląska, gdzie zaginęły. Dodać należy, że w 1944 r., gdy do Przemyśla zbliżał się front, ks.

${ }^{100} \mathrm{~S}$. Zych, Diecezja przemyska obrzadku łacińskiego w warunkach okupacji niemieckiej i sowieckiej 1939-1944/1945, Przemyśl 2011, s. 140.

${ }^{101}$ Stefan Momidłowski - urodził się w 1872 r. w Rzeszowie. Po maturze wstąpił do Seminarium Duchownego w Przemyślu, gdzie w 1894 r. przyjął święcenia kapłańskie. Po kilkumiesięcznym wikariacie w Głogowie wyjechał do Rzymu, gdzie w 1900 r. obronił doktorat z filozofii i teologii na Papieskim Uniwersytecie Gregoriańskim. W latach 1905-1950 pełnił funkcję dyrektora Muzeum Diecezjalnego w Przemyślu, był też wykładowcą, wicerektorem i rektorem Seminarium Duchownego. Kanonik kapituły katedralnej, scholastyk, a w 1931 r. otrzymał godność infułata. Zmarł w Przemyślu w 1958 r. Zob. F. Misiąg, Wspomnienia pośmiertne. Śp. Ks. Infułat dr Stefan Momidłowski (1872-1958), KDP 1959, R. 45, z. 6-8, s. 152-162.

102 S. Momidłowski, Wspomnienia pośmiertne. Śp. ks. dr Jan Kwolek, KDP 1958, R. 44, z. 9-10, s. 270 .

${ }^{103}$ AAPrz, Teczka „Archiwum. Zabranie i starania o zwrot”, b. sygn., Pismo Dyrekcji Archiwów Generalnego Gubernatorstwa do Kurii Biskupiej ob. łac. w Przemyślu z 15 V 1942 r., b. s.; Kopie pism ks. J. Kwolka do władz okupacyjnych z 14 i 29 VII 1942 r.

${ }^{104}$ Hieronim Kocyłowski - urodził się 24 IX 1910 r. w Posadzie Olchowskiej k. Sanoka. Uczęszczał do gimnazjum w Sanoku, a następnie wstąpił do Seminarium Duchownego w Przemyślu, gdzie 24 VI 1934 r. przyjął święcenia kapłańskie. Po nich był wikariuszem w Jasienicy Rosielnej, a następnie kapelanem bpa Franciszka Bardy i notariuszem kurii. W latach 1936-1939 studiował w Rzymie prawo kanoniczne, a po powrocie ponownie pełnił funkcję notariusza. Był dyrektorem „Caritasu” i referentem w kurii do spraw duszpasterstwa. Ze względu na naciski władz komunistycznych opuścił diecezję i dopiero po październiku 1956 r. powrócił do niej obejmując funkcję administratora w Staromieściu. Wskutek szykan ponownie musiał wyjechać, udając się do archidiecezji wrocławskiej, gdzie zmarł w 1983 r. Zob. AAPrz, Tabela służbowa ks. Hieronima Kocyłowskiego, b. sygn.

${ }^{105}$ AAPrz, Teczka „Archiwum. Zabranie i starania o zwrot”, b. sygn., Protokół przejęcia archiwaliów przez ks. Hieronima Kocyłowskiego z dnia 5 VI 1943 r., b. s. 
J. Kwolek, obawiając się prawdopodobnie przekształcenia przez Niemców miasta w twierdzę, wywiózł 129 cenniejszych ksiąg do Brzozowa, skąd powróciły one po zakończeniu działań wojennych ${ }^{106}$. Po latach okupacji przemyski archiwista rozpoczął usilne starania mające na celu odnalezienie utraconych zbiorów archiwalnych, ale wysiłki te okazały się bezowocne ${ }^{107}$.

\section{Porządkowanie archiwaliów}

Każde archiwum, chcąc spełniać jedną z podstawowych swoich funkcji, jaką jest służenie bogactwem zbiorów, musi wpierw zostać należycie uporządkowane i opisane, dzięki czemu zarówno osoby za nie odpowiedzialne, jak i badacze otrzymają informację o najważniejszej tematyce zasobu i bez problemów odnajdą interesujące ich źródła. Zdając sobie z tego sprawę, ks. J. Kwolek już od 1916 r. jako sekretarz konsystorza przystąpił do porządkowania przemyskich archiwaliów, a prace te zintensyfikował, gdy w 1918 r. bp J. S. Pelczar mianował go archiwariuszem kurii diecezjalnej. Dzięki temu do 1924 r. przez ręce przemyskiego kanonisty przeszedł każdy stary dokument zgromadzony w kurii, który ogólnie został opisany i umieszczony tak, by w razie potrzeby można go było w krótkim czasie odnaleźć. Bardziej zaawansowane prace porządkowe nastąpiły dopiero wówczas, gdy archiwum otrzymało większe możliwości lokalowe (1926 r.). Dzięki temu jego opiekun wiele ksiąg oprawił (lub oprawy naprawił) i zaopatrzył w numery oraz sygnatury ${ }^{108}$. W 1927 r. ks. J. Kwolek dla każdej parafii przydzielił osobną teczkę, w której umieścił jej akta zarówno starsze, jak i nowsze, ale już w roku następnym zarówno akta luźne parafii, jak i biskupstwa zaczął dzielić na starsze (do połowy XIX w.) oraz nowsze, przy czym te pierwsze układał systematycznie, przygotowując do zszycia. Dodać należy, że w ten sposób nie zajmował się jedynie dokumentami już obecnymi W archiwum, lecz również tymi, które nieustannie nadsyłano z parafii ${ }^{109}$. W $1929 \mathrm{r}$. porządkowano tylko dokumenty, które przyszły do archiwum z zewnątrz, co było spowodowane chorobą dyrektora ${ }^{110}$, jednakże w roku następnym uporządkowane stare dokumenty (do połowy XIX w.) oddano do zszycia introligatorowi, dzięki czemu archiwum wzbogaciło się o 318 tomów akt ${ }^{111}$. Ta praca ostatecznie została zakończona w $1931 \mathrm{r} .{ }^{112}$ Oprócz akt parafialnych, porządkowano również pergaminy. Po ich spisaniu, zostały one włożone do specjalnych kopert na których zanotowano ich ogólną treść ${ }^{113}$. W 1932 r. koperty te w porządku chronologicznym umieszczono

\footnotetext{
${ }^{106}$ S. Zych, Losy Archiwum Diecezjalnego w Przemyślu w latach II wojny światowej, „Prace Historyczno-Archiwalne", t. 17 (2006), s. 187-188.

${ }^{107}$ Archiwa Kościoła katolickiego w Polsce, s. 85.

${ }^{108}$ J. Kwolek, Archiwa diecezji przemyskiej, s. 25-27.

${ }^{109}$ Sprawozdanie 1927 i 1928, s. 68.

${ }^{110}$ Sprawozdanie 1929, s. 59.

${ }^{111}$ Sprawozdanie 1930, s. 46.

${ }^{112}$ Sprawozdanie 1931, s. 30.

${ }^{113}$ Sprawozdanie 1927 i 1928, s. 69.
} 
w zakupionych na ten cel pudłach ${ }^{114}$. Dyrektor spisał też posiadane przez archiwum ekstrakty metrykalne i podał ich katalog w KDP ${ }^{115}$.

Uporządkowane księgi i pergaminy należało również odpowiednio opisać na kartach inwentarzowych. Już jesienią 1928 r. klerycy umieścili na nich pięćset ksiąg parafialnych, zaopatrując je również w paginację ${ }^{116}$. W 1929 r. spisywano $\mathrm{w}$ zasadzie tylko nowe przybytki ${ }^{117}$, ale $\mathrm{w}$ roku następnym inwentarz kartkowy obejmował już 800 ksiąg ${ }^{118}$, zaś po jego ukończeniu w 1931 r. zawierał już ponad 1100 kart. Wszystkie te księgi otrzymały również paginację. Inwentarz kartkowy opracowywany przez kleryków obejmował nie tylko księgi, lecz również pergaminy. W $1931 \mathrm{r}$. zawierał on już 134 numery ${ }^{119}$, a w roku następnym został ukończony ${ }^{120}$. W 1933 r. inwentarz kartkowy ksiąg i pergaminów skompletowano, dopisując jeszcze do niego 78 pozyskanych ksiąg i 20 pergaminów, a każdy nowy nabytek natychmiast otrzymywał kartę inwentarzową ${ }^{121}$. Znalazł on swoje miejsce w specjalnie na ten cel przygotowanych pudłach ${ }^{122}$. Gdy nie należało się spodziewać większych przybytków ksiąg, wówczas przystąpił dyrektor archiwum do ich numeracji. Każda księga i przynależna jej karta otrzymały odpowiednie numery od 1 do 2007, które zapisano również na szafach. Spis ten wyglądał następująco:

nr 1-154 - księgi konsystorskie od 1470 r. do XIX w.

nr 155-192 - wizytacje generalne XVII-XVIII w., nr 193-228 - księgi mensy biskupiej XVIII-XIX w., nr 229-257 - seminarium duchowne XVIII-XIX w., nr 258-286 - akta sesji kapitulnych 1788-1802 r., nr 287-291 - bractwo kapłanów ziemi sanockiej XVI-XVIII w., nr 292-353 - dekanaty w porządku alfabetycznym, nr 354-409 - parafia Przemyśl, nr 410-1995 - inne parafie w porządku alfabetycznym, nr 1996-2007- suplement ${ }^{123}$.

Po nadaniu tejże numeracji wszelkie archiwalia nowo przybyłe otrzymywały kolejne numery (od 2008) i były układane w następnych szafkach. Dodać należy, że ta numeracja nie obejmowała ksiąg protokołów registratury, ksiąg rachunkowych, nowszych i innych ${ }^{124}$.

\footnotetext{
${ }^{114}$ Sprawozdanie 1932, s. 23.

${ }^{115}$ Sprawozdanie 1927 i 1928, s. 69.

${ }^{116}$ Ibidem.

${ }^{117}$ Sprawozdanie 1929, s. 59.

${ }^{118}$ Sprawozdanie 1930, s. 47.

${ }^{119}$ Sprawozdanie 1931, s. 30

${ }^{120}$ Sprawozdanie 1932, s. 23.

${ }^{121}$ Sprawozdanie 1933, s. 83.

${ }^{122}$ Sprawozdanie 1931, s. 31.

${ }^{123}$ Sprawozdanie 1934, s. 97.

${ }^{124}$ Ibidem.
} 
Zdając sobie sprawę z faktu, że inwentarz kartkowy nie zawierał dokładnej treści ksiąg, w 1931 r. przy pomocy kleryków ks. J. Kwolek rozpoczął spisywanie ich indeksów. Ta mozolna praca była przewidziana na kilka lat, a jej zakończenie miało zostać zwieńczone przygotowaniem do druku katalogu ${ }^{125}$. W 1932 r. zindeksowano zaledwie osiem ksiąg ${ }^{126}$, jednakże do końca 1934 r. indeksy otrzymały już ogółem 132 księgi, lecz pozostawały jeszcze $273^{127}$. Do końca 1936 r. ogółem zindeksowano $419 \mathrm{ksiąg}$, a pozostało jedynie $30^{128}$. Mimo więc stosunkowo niewielkiej ich liczby, tej pracy nie ukończono, a tym samym nie udało się również opracować katalogu. Prawdopodobnie przyczynił się do tego stan zdrowia dyrektora archiwum, nadmiar innych obowiązków oraz brak zainteresowania jego pracą ze strony przełożonych ${ }^{129}$.

\section{Troska o bazę lokalową archiwum i bibliotekę podręczną}

Każde archiwum, aby mogło wypełniać swoje zadanie przechowywania starych dokumentów oraz udostępniania ich badaczom, potrzebuje odpowiedniej bazy lokalowej. Początkowo dokumenty archiwalne nie były oddzielone odrębnym pomieszczeniem od bieżących akt, lecz znajdowały się w szafach kancelarii konsystorza. Gdy archiwariuszem kurii diecezjalnej został mianowany ks. J. Kwolek, wówczas stare archiwalia znalazły miejsce w odrębnym pomieszczeniu, w szafach zakupionych na polecenie bpa J. S. Pelczara. Tenże rządca diecezji polecił również w takich szafach umieścić część archiwaliów znajdujących się w bibliotece diecezjalnej. Jak już wspomniano, w 1926 r. bp A. Nowak przekazał na potrzeby archiwum dwuizbowy lokal w przebudowanym budynku kurii ${ }^{130}$. W ten sposób główna siedziba archiwum diecezjalnego znalazła miejsce w budynku kurii przy ul. Katedralnej $20 \mathrm{~A}$, a magazyn pomocniczy w dawnym diecezjalnym budynku (pojezuickim) przy pl. Czackiego $10^{131}$. Ten podział archiwaliów według ks. J. Kwolka nie był korzystny zarówno dla pracowników kurii, którzy chcieli skorzystać ze starych dokumentów w trakcie bieżących prac administracyjnych, jak i dla badaczy. Poza tym budynek przy pl. Czackiego nie był opalany, stąd też zgromadzone materiały mogły ulec procesowi butwienia ${ }^{132}$. W magazynie głównym umieszczono księgi, akta, dokumenty, jak również protokoły registratur i bibliotekę pomocniczą. Z kolei w magazynie pomocniczym znalazła schronienie registratura z czasów austriackich i ekstrakty metrykalne. Pomieszczenia w budynku kurii jak na owe czasy zostały wyposażone w sposób nowoczesny, gdyż otrzymały elektryfikację i ogrzewanie w postaci pieców kaflowych. W 1928 r. zbiory magazynu głównego zabezpieczono

\footnotetext{
${ }^{125}$ Sprawozdanie 1931, s. 31.

${ }^{126}$ Sprawozdanie 1933, s. 84.

127 Sprawozdanie 1934, s. 97.

${ }^{128}$ Sprawozdanie 1936, s. 115.

${ }^{129}$ J. Patryn, op. cit., s. 60.

${ }^{130}$ J. Kwolek, Archiwa diecezji przemyskiej, s. 25-26.

${ }^{131}$ Ibidem, s. 28-29.

132 J. Patryn, op. cit., s. 44.
} 
również przed ogniem przez dodanie drugich drzwi żelaznych, zaopatrzenie okien w metalowe okiennice, a pieców w specjalnie spreparowane drzwiczki. W tym samym roku zakupiono też dwie szafy (zamykaną i otwartą) ${ }^{133}$. W 1929 r. w lokalu głównym został unowocześniony system oświetlenia i dodatkowo przed ogniem zabezpieczono drzwi główne ${ }^{134}$, zaś w 1930 r. zakupiono dużą szafę ${ }^{135}$.

Ksiądz J. Kwolek od erygowania archiwum dążył do tego, by posiadało ono również dobrze zaopatrzoną bibliotekę podręczną, mogącą ułatwiać badaczom eksplorację zbiorów. Wspominał już o tym statut, którego XX artykuł brzmiał następująco: „Archiwum gromadzi i stale uzupełnia wszelkie druki urzędowe, jak schematyzmy, kurendy, kroniki, rozporządzenia, ustawy itp., a nadto wszelkie inne publikacje do historji diecezji, oraz książki pomocnicze związane z badaniami archiwalnemi" ${ }^{136}$. Księgozbiór tejże biblioteki złożony był z dawnych zasobów pozyskanych w kurii, ale stale uzupełniano go o źródła drukowane odnalezione w parafiach, pozycje wydzielone $\mathrm{z}$ księgozbioru biskupiego biblioteki diecezjalnej, uzyskane od prywatnych darczyńców czy też w końcu zakupione ze środków archiwalnych. W jego skład wchodziły również zdeponowane tu niektóre pozycje książkowe z biblioteki seminaryjnej, jak również z prywatnych zasobów dyrektora archiwum. Ogółem zasób biblioteki archiwalnej zawierał: Schematyzmy diecezji przemyskiej od 1805 r., Directoria przemyskie od 1795 r. (z pewnymi brakami), Kurendy biskupie z lat 1719-1900, komplet KDP, Synody diecezji przemyskiej, Schematyzmy, Directoria i Synody innych diecezji oraz różnego rodzaju pozycje historyczne i prawnicze wykorzystywane w prowadzeniu badań ${ }^{137}$.

Jak już wspomniano, biblioteka archiwalna co pewien czas była uzupełniana między innymi przez stare źródła drukowane nadsyłane z parafii. Z tego też względu ks. J. Kwolek dbał, by w KDP ukazywały się ogłoszenia z prośbą o przesłanie wskazanych przez niego roczników Schematyzmów diecezjalnych, Directoriów, Kurend, Synodów, austriackich ustaw, patentów i cyrkularzy, jak również brakujących tomów encyklopedii, bibliografii, herbarzy i książek z zakresu prawa, historii diecezji oraz poszczególnych parafii. Dyrektor zachęcał do ich przekazania bezpłatnego lub odsprzedania ${ }^{138}$. Taki sposób uzupełniania zasobów bibliotecznych przynosił efekty, o czym może świadczyć podziękowanie dla darczyńców zawarte w sprawozdaniu archiwalnym z 1929 r. ${ }^{139}$

\footnotetext{
${ }^{133}$ Sprawozdanie 1927 i 1928, s. s. 67-68.

${ }^{134}$ Sprawozdanie 1929, s. 59.

${ }^{135}$ Sprawozdanie 1930, s. 46.

${ }^{136}$ Statut organizacyjny, s. 64.

${ }^{137}$ Sprawozdanie 1927 i 1928, s. 71-73.
}

${ }^{138}$ Archiwum diecezjalne, KDP 1928, R. 28, z. 8-9, s. 181; Archiwum diecezjalne, KDP 1929, R. 29, z. 3-4, s. 60; Archiwum diecezjalne poszukuje, KDP 1931, R. 31, z. 1, s. 25-26; Archiwum diecezjalne poszukuje, KDP 1932, R. 32, z. 1, s. 35.

${ }^{139}$ Sprawozdanie 1929, s. 61. 
Inną formą powiększania zasobu biblioteki archiwalnej był zakup potrzebnych wydawnictw. Jak informował zarządca archiwum w $1929 \mathrm{r}$. w ten sposób pozyskano Bibliografię Polska Estreicherów (t. 9-27), Stownik geograficzny Królestwa Polskiego (14 tomów) oraz Matricularum Regni Poloniae Summaria Wierzbowskiego $\left(8\right.$ tomów ${ }^{140}$. O wszelkich nowych pozycjach książkowych (zarówno otrzymanych jak i zakupionych) dyrektor informował w sprawozdaniach archiwalnych umieszczanych w $\mathrm{KDP}^{141}$. W 1934 r. podawał, że archiwum diecezjalne było jedyną instytucją naukową w Przemyślu dysponującą kompletnymi bibliografiami Jochera, Finkla i Estreichera ${ }^{142}$.W sprawozdaniach dyrektor archiwum wymieniał również kwoty przeznaczane rokrocznie na zakup nowych książek oraz ich oprawę. Szczegółowe dane ukazuje tabela.

Tabela 2. Wydatki Archiwum Diecezjalnego w Przemyślu poniesione na zakup i oprawę książek dla biblioteki podręcznej w latach 1927-1936

\begin{tabular}{|c|c|}
\hline Rok & Kwota \\
\hline 1927 & 377 zł $60 \mathrm{gr}$ \\
\hline 1928 & $404 \mathrm{zł} 45 \mathrm{gr}$ \\
\hline 1929 & $1093 \mathrm{zł}$ \\
\hline 1930 & $1205 \mathrm{zł} 95 \mathrm{gr}$ \\
\hline 1931 & $846 \mathrm{zł} 39 \mathrm{gr}$ \\
\hline 1932 & $711 \mathrm{zł} 50 \mathrm{gr}$ \\
\hline 1933 & $589 \mathrm{zł} 85 \mathrm{gr}$ \\
\hline 1934 & $800 \mathrm{zł} 32 \mathrm{gr}$ \\
\hline 1935 & $477 \mathrm{zł} 95 \mathrm{gr}$ \\
\hline 1936 & $403 \mathrm{zł} 35 \mathrm{gr}$ \\
\hline Razem & $6910 \mathrm{zł} 36 \mathrm{gr}$ \\
\hline
\end{tabular}

Źródło: Sprawozdanie 1927 i 1928, s. 73; Sprawozdanie 1929, s. 61; Sprawozdanie 1930, s. 50; Sprawozdanie 1931, s. 34; Sprawozdanie 1932, s. 25; Sprawozdanie 1933, s. 85; Sprawozdanie 1934, s. 98; Sprawozdanie 1935, s. 203; Sprawozdanie 1936, s. 116.

Jak wynika z tabeli, tylko w latach 1927-1936 ks. J. Kwolek na zakup i oprawę książek dla biblioteki archiwalnej przeznaczył kwotę 6910 zł i 36 gr, a wziąwszy pod uwagę również nabytki spływające od ofiarodawców daje nam to wyobrażenie doskonale wyposażonego księgozbioru, który mógł służyć historykom.

\footnotetext{
${ }^{140}$ Ibidem, s. 60-61.

${ }^{141}$ Sprawozdanie 1930, s. 49-50; Sprawozdanie 1931, s. 33; Sprawozdanie 1932, s. 22-23; Sprawozdanie 1933, s. 82-83; Sprawozdanie 1934, s. 96; Sprawozdanie 1935, s. 201-202; Sprawozdanie 1936, s. 114-115.

${ }^{142}$ Sprawozdanie 1934, s. 96.
} 
Niestety ten bogaty zbiór biblioteki archiwalnej w wyniku II wojny światowej w znacznej mierze został rozproszony ${ }^{143}$. Ksiądz Kwolek starał się go jednak porządkować i uzupełniać, a z tej racji, że zarówno władze okupacyjne, jak i komunistyczne nie pozwalały drukować KDP, przemyski archiwista systematycznie gromadził okólniki oraz rozporządzenia władz diecezjalnych, jak również artykuły z prasy świeckiej podejmujące problematykę relacji państwa i Kościoła ${ }^{144}$.

Dodać należy, że ks. J. Kwolek w trakcie II wojny światowej uratował również sporą część zasobu Biblioteki Kapituły Katedralnej w Przemyślu (do śmierci był jej kustoszem $)^{145}$, a w okresie okupacji sowieckiej prawobrzeżnej części miasta prawdopodobnie opiekował się Biblioteką Diecezjalną ${ }^{146}$.

\section{Udostępnianie archiwaliów}

Już w II artykule Statutu Archiwum Diecezjalnego w Przemyślu wyraźnie zaznaczono, że instytucja ta ma na celu nie tylko gromadzenie i przechowywanie źródeł historycznych, lecz również ich udostępnianie ${ }^{147}$. Jeszcze przed wejściem wspomnianego dokumentu w życie i erygowaniem archiwum, w latach 1901-1926 ze zbiorów kościelnych korzystało nie więcej niż dwie osoby rocznie. Liczba ta znacznie wzrosła, gdy przemyski pasjonat historii zatroszczył się o to, by otrzymało ono pracownię naukową umieszczoną w lokalu sądu diecezjalnego ${ }^{148}$. Szczegółowe dane dotyczące ilości osób przeprowadzających kwerendę w przemyskim archiwum kościelnym ukazuje tabela.

Tabela 3. Liczba osób korzystających z zasobów Archiwum Diecezjalnego oraz ilość udzielonych kwerend pisemnych w latach 1927-1936

\begin{tabular}{|c|c|c|c|}
\hline Rok & $\begin{array}{c}\text { Liczba osób } \\
\text { świeckich }\end{array}$ & $\begin{array}{c}\text { Liczba osób } \\
\text { duchownych }\end{array}$ & $\begin{array}{c}\text { Ilość kwerend } \\
\text { pisemnych }\end{array}$ \\
\hline 1927 & 4 & 5 & 1 \\
\hline 1928 & 5 & 10 & 14 \\
\hline 1929 & 1 & 7 & 12 \\
\hline 1930 & 4 & 11 & 20 \\
\hline 1931 & 10 & 12 & 25 \\
\hline 1932 & 11 & 16 & 20 \\
\hline
\end{tabular}

${ }^{143}$ S. Zych, Diecezja przemyska, s. 143.

${ }^{144}$ AAPrz, Okólniki bpa Franciszka Bardy, b. sygn.; ibidem, Okólniki diecezji przemyskiej 1939-1947, b. sygn.; ibidem, Okólniki diecezji przemyskiej 1948-1949, b. sygn.; Relacja: ks. Henryk Borcz $(71$ 1.), Przemyśl, 11 VI 2021 r. [Relacja w zbiorach autora].

${ }^{145}$ E. Ślemp, Biblioteki kościelne i klasztorne Przemyśla, [w:] Z dziejów bibliotek przemyskich. Praca zbiorowa z okazji sześćdziesięciolecia Przemyskiej Biblioteki Publicznej (1947-2007), red.

A. Siciak, Przemyśl 2009, s. 211.

${ }^{146}$ S. Zych, Diecezja przemyska, s. s. 144.

${ }^{147}$ Statut organizacyjny Archiwum Diecezjalnego, s. 61.

${ }^{148}$ Sprawozdanie 1927 i 1928, s. 74. 


\begin{tabular}{|c|c|c|c|}
\hline 1933 & 9 & 15 & 25 \\
\hline 1934 & 4 & 20 & 28 \\
\hline 1935 & 12 & 20 & 38 \\
\hline 1936 & 13 & 11 & 30 \\
\hline Razem & 73 & 127 & 213 \\
\hline
\end{tabular}

Źródło: Sprawozdanie 1927 i 1928, s. 74; Sprawozdanie 1929, s. 62; Sprawozdanie 1930, s. 51; Sprawozdanie 1931, s. 33; Sprawozdanie 1932, s. 24; Sprawozdanie 1933, s. 84; Sprawozdanie 1934, s. 97-98; Sprawozdanie 1935, s. 202; Sprawozdanie 1936, s. 115-116.

Jak wynika z tabeli, tylko w latach 1927-1936 z zasobów Archiwum Diecezjalnego w Przemyślu skorzystało łącznie 200 osób, zaś jego dyrektor korespondencyjnie udzielił 213 odpowiedzi. Łatwo zauważyć, że wśród badaczy przeważały osoby duchowne, co można tłumaczyć ich zainteresowaniami naukowymi, zdecydowanie częściej związanymi z tematyką kościelną niż historyków świeckich. Z każdym rokiem liczba korzystających ze zbiorów archiwalnych wzrastała, co mogło być dobrą prognozą na kolejne lata jego funkcjonowania.

Historycy korzystający z zasobów Archiwum Diecezjalnego w Przemyślu według 15 punktu Regulaminu pracowni mieli obowiązek złożenia przynajmniej jednego egzemplarza pracy napisanej na podstawie uzyskanych w nim źródeł ${ }^{149}$. W ten sposób dyrektor placówki nie tylko poszerzał zbiór biblioteki podręcznej, ale również uzyskiwał informacje na temat drukowanych publikacji naukowych opartych w całości lub części na przemyskich materiałach. Na podstawie sprawozdań zamieszczonych w KDP można przytoczyć choć niektóre tytuły:

1. Kałwa Piotr ks., Działalność kościelna Katarzyny Wapowskiej w ziemi sanockiej, Lwów 1931, ss. 56.

2. Kramarz Walerjan, Ladenberger Tadeusz, Rozmieszczenie ludności rzym.-kat. w diecezji przemyskiej wr. 1785, Lwów 1931, ss. 32 i mapa diecezji.

3. Persowski Franciszek, Księga sadowa wsi Markowej w powiecie przeworskim, Lwów 1931, ss. 10.

4. Persowski Franciszek, Osadnictwo w dorzeczu średniego biegu Sanu, próba rekonstrukcji krajobrazu z XV, Lwów 1931, ss. 17 i mapka (praca częściowo oparta na źródłach z Archiwum Diecezjalnego).

5. Arłamowski Kazimierz, Dzieje przemyskich cechów rzemieślniczych w dawnej Polsce, Przemyśl 1931.

6. Kraśnicki Andrzej ks., Posty w dawnej Polsce, Lwów 1931.

7. Kałwa Piotr, Powstanie i rozwój polskiej kolędy jako daniny kościelnej, Lwów 1933.

8. Bednarski Stanisław ks., Upadek i odrodzenie szkót jezuickich w Polsce, Kraków 1933.

\footnotetext{
${ }^{149}$ Regulamin pracowni Archiwum Diecezjalnego, s. 68.
} 
9. Dörflerówna Anna, Materiały do historii miasta Sambora 1390-1795, Lwów 1936.

10. Lasek J. ks., Cześć Najświętszego Sakramentu w diecezji przemyskiej, Przemyśl $1936^{150}$.

W trakcie II wojny światowej z wiadomych względów archiwum w zasadzie nie udostępniało swoich zbiorów badaczom, choć prawdopodobnie na podstawie uzyskanych w nim materiałów napisano pracę dotyczącą Lutczy, a poza tym naukowcy niemieccy przeszukiwali księgi metrykalne znajdujące się w budynku przy placu Czackiego. Ci ostatni prawdopodobnie próbowali uzyskać informacje na temat osadnictwa niemieckiego ${ }^{151}$. Zarówno w trakcie okresu okupacji, jak i w innych latach z zasobów archiwum korzystał jego dyrektor, opracowując przede wszystkim biogramy do Polskiego Słownika Biograficznego następujących osób: Fryderyk Alembek (Alepech), Antonin z Przemyśla, Adam Bielecki, Ludwik Bikowski, Mikołaj Błażejowski herbu Odrowąż, Jan Kazimierz de Alten Bokum, Jan Borukowski z Bielina, Stanisław Byliński, Piotr Chrząstowski herbu Kościerza, Jan Dziaduski, Eryk z Winsen, Franciszek Faygiel, Henryk Firlej, Józef Karol Fischer, Konstanty Fredro, Wojciech Galant ${ }^{152}$. Po zakończeniu wojny ks. J. Kwolek w zasadzie udostępnianie zbiorów ograniczył do kwerend pisemnych ${ }^{153}$.

\section{Udzial w opracowaniu naukowych podstaw archiwistyki oraz troska o zabezpieczenie zbiorów kościelnych w Polsce}

Ksiądz J. Kwolek nie tylko podejmował działania praktyczne, mające na celu uporządkowanie, zabezpieczenie i udostępnienie badaczom archiwaliów diecezjalnych, lecz starał się o rozwijanie teoretycznych zasad naukowych w tej dziedzinie, jak również podejmował szereg zabiegów mających na celu wydanie przez władze kościelne w Polsce odpowiednich decyzji zabezpieczających zbiory eklezjalne.

Już w 1927 r. ukazała się jego broszura pt. Archiwa diecezji przemyskiej ob. łac., w której omówił historię powierzonej jego kierownictwu placówki, jak również jej organizację wewnętrzną i zasoby. Oprócz tego zawarł w niej charakterystykę mniejszych archiwów kościelnych Przemyśla i ukazał zasoby metrykalne archiwów parafialnych w ówczesnej diecezji przemyskiej. Całości dopełniał dodatek zawierający Statut organizacyjny Archiwum Diecezjalnego przy Kurii Biskupiej o. t. w Przemyślu oraz Regulamin jego pracowni ${ }^{154}$. Należy dodać, że wspomniana broszura spotkała się z pozytywnymi recenzjami zarówno w pismach naukowych, jak i publicystycznych ${ }^{155}$. W roku następnym opublikował opracowanie Ekstrakty

${ }^{150}$ Sprawozdanie 1931, s. 33-34; Sprawozdanie 1932, s. 24; Sprawozdanie 1933, s. 85; Sprawozdanie 1936, s. 115-116.

${ }^{151}$ S. Zych, Diecezja przemyska, s. 143-144.

${ }^{152}$ T. Pudłocki, Ksiadz doktor Jan Kwolek, „Rocznik Gimnazjalny”, nr 3 (82), 1998, s. 153.

153 J. Patryn, op. cit., s. 101.

${ }^{154}$ J. Kwolek, Archiwa diecezji przemyskiej, passim.

${ }^{155}$ Sprawozdanie 1927 i 1928, s. 69. 
metrykalne w Archiwum Diecezjalnem Przemyskiem, w którym ukazał przepisy kościelne dotyczące tego zagadnienia, a przede wszystkim zawarł katalog ekstraktów znajdujących się w kierowanej przez siebie instytucji156.

Ksiądz J. Kwolek jako jedyny zarządca archiwum kościelnego w Polsce przez kilka lat publikował sprawozdania ukazujące całość funkcjonowania tejże placówki naukowej. Już w Statucie z 1927 r. zaznaczył, że dyrektor „zdaje z początkiem każdego roku kalendarzowego (a w razie potrzeby także częściej) Ordynarjuszowi sprawozdanie: o stanie archiwum, o zaszłych w niem zmianach i prowadzonych pracach, o dochodach i wydatkach, o jego potrzebach i grożących niebezpieczeństwach"157. W KDP oraz w rozsyłanych odbitkach umieścił przemyski archiwariusz dziewięć sprawozdań (pierwsze za lata 1927 i 1928, a ostatnie za rok 1936), które zazwyczaj składały się z pięciu części:

1. Prace organizacyjne,

2. Przybytki archiwalne,

3. Biblioteka pomocnicza,

4. Pracownia naukowa,

5 Sprawozdanie rachunkowe ${ }^{158}$.

Jak informował sam dyrektor, sprawozdania te pozwoliły wyeksponować przemyskie archiwum na łamach ogólnopolskich - a nawet zagranicznych - czasopism naukowych, gdyż wielu badaczy, opisując zasoby historyczne w naszym kraju, odnosiło się do nich, nie szczędząc przy tym słów uznania ${ }^{159}$. W tej sytuacji trudno odnaleźć powody zaprzestania po 1936 r. pisania tychże sprawozdań. Można spekulować, że były to problemy zdrowotne ks. J. Kwolka lub narastające u niego poczucie niezrozumienia dla podejmowanych wysiłków ze strony przełożonych ${ }^{160}$.

Ksiądz J. Kwolek starał się również upowszechniać zamiłowanie do pracy archiwalnej, a tym samym do starych dokumentów kościelnych także u młodego pokolenia. W tym celu już od $1920 \mathrm{r}$. w ramach studiów seminaryjnych prowadził seminarium archiwalne oraz angażował kleryków do pracy w archiwum ${ }^{161}$. Myślał również o swoim następcy, a nawet pomocniku, stąd też sugerował rządcy diecezji, by wysłał on młodego księdza na studia historyczno-archiwalne ${ }^{162}$. Swoimi refleksjami i zabiegami w tej kwestii dzielił się w listach do ks. J. Fijałka pisząc do niego w czerwcu 1928 r.: „Z Przemyślem wiąże mnie dziś tylko archiwum, myślę nad znalezieniem następcy, bo człek nie wieczny i całkiem tu niepewny, może mi się

${ }^{156}$ J. Kwolek, Ekstrakty metrykalne, s. 231-249.

${ }^{157}$ Statut organizacyjny Archiwum Diecezjalnego, s. 63.

${ }^{158}$ Sprawozdanie 1927 i 1928, s. 67-74; Sprawozdanie 1929, s. 59-62; Sprawozdanie 1930, s. 46-51; Sprawozdanie 1931, s. 30-34; Sprawozdanie 1932, s. 21-25; Sprawozdanie 1933, s. 81-85; Sprawozdanie 1934, s. 95-98; Sprawozdanie 1935, s. 201-203; Sprawozdanie 1936, s. 114-116.

${ }^{159}$ Sprawozdanie 1932, s. 24.

${ }^{160}$ J. Patryn, op. cit., s. 62.

${ }^{161}$ Ibidem, s. 32, 95.

${ }^{162}$ Ibidem, s. 44. 
uda nareszcie uzyskać to, aby posłano kogoś na studium historii, wtedy z czystym sumieniem poszedłbym stąd, bo widzę, że tu się nie uchowam" "163. Zaś rok później: „Kwestię mojego następstwa w archiwum na wypadek mej śmierci dokładnie omawiałem z Biskupem, byle powołał do kurii osobę przeze mnie wskazaną, to archiwum nie zginie i doczeka się inwentaryzacji" 164 .

Przemyski archiwista - jak już zostało wspomniane - nie tylko biernie oczekiwał na ocenę swojej pracy ze strony innych naukowców, lecz starał się dzielić swoimi doświadczeniami, chcąc w ten sposób pobudzić archiwistykę kościelną do wyjścia z marazmu. 11 kwietnia 1928 r. na I Zjeździe Polskiego Towarzystwa Teologicznego wygłosił referat pt. Naukowa organizacja archiwów kościelnych ${ }^{165}$, opublikowany najpierw w czasopiśmie naukowym „Archeion” ${ }^{166}$, a dwa lata później - już poszerzony - w „Przeglądzie Teologicznym” ${ }^{167}$. W nim to ks. J. Kwolek zwracał uwagę na priorytetowe kwestie dotyczące zabezpieczenia archiwaliów eklezjalnych. Przede wszystkim wskazywał na osobę odpowiednio przygotowaną do pracy archiwisty oraz właściwy lokal. Dopiero po spełnieniu tych podstawowych warunków można było - według referenta - przystąpić do porządkowania, konserwacji i sporządzania inwentarza oraz katalogu zbiorów. W dalszej części pracy autor wykazał potrzebę koncentracji w archiwum diecezjalnym archiwaliów parafialnych, a całości miały dopełnić regulacje prawne w postaci statutu i regulaminu ${ }^{168}$.

Inną formą upowszechniania wiedzy archiwalnej wśród duchowieństwa, a tym samym zwrócenia uwagi na potrzebę organizacji archiwów kościelnych, było według ks. J. Kwolka utworzenie w jednym z czasopism religijnych działu dotyczącego archiwistyki kościelnej. Między innymi dzięki jego zabiegom w 1936 r. takowy powstał w „Ateneum Kapłańskim”, a przemyski kanonista i historyk rozpoczął z nim współpracę ${ }^{169}$. Jeszcze w listopadzie 1935 r. pisał o tym projekcie do ks. J. Fijałka w następujący sposób: „Chcę podzielić się wiadomością dobrą: otwieramy dział archiwalny w «Ateneum Kapłańskim». Piszę w liczbie mnogiej, bo choć się od współredakcji wymówiłem, obiecałem współpracę i właśnie napisałem artykuł programowy do zeszytu grudniowego. Ma być co kwartał 10 stronic"170. Głównym zadaniem tej rubryki według ks. J. Kwolka było zainteresowanie archiwaliami szerokich mas duchowieństwa, upowszechnianie wiedzy w tej dziedzinie, a ostatecznie utworzenie we wszystkich diecezjach polskich archiwów na odpowiednim poziomie

${ }^{163}$ Polska Akademia Umiejętności Biblioteka Naukowa PAU i PAN w Krakowie, sygn. 4685, Korespondencja Jana Kwolka z Janem Fijałkiem, List ks. Jana Kwolka do ks. Jana Fijałka z czerwca 1928 r.

${ }^{164}$ Ibidem, List ks. Jana Kwolka do ks. Jana Fijałka z dnia 2 V 1929 r.

${ }^{165}$ Sprawozdanie 1927 i 1928, s. 74.

${ }^{166}$ J. Kwolek, Naukowa organizacja archiwów diecezjalnych, „Archeion”, t. 4: 1928, s. 15-36.

${ }^{167}$ Idem, Naukowa organizacja archiwów kościelnych, „Przegląd Teologiczny”, R. 11: 1930, s. 1-37.

${ }^{168}$ Ibidem, passim.

169 J. Patryn, op. cit., s. 96.

${ }^{170}$ Polska Akademia Umiejętności Biblioteka Naukowa PAU i PAN w Krakowie, sygn. 4685, Korespondencja Jana Kwolka z Janem Fijałkiem, List ks. Jana Kwolka do ks. Jana Fijałka z dnia 3 XI 1935 r. 
naukowym ${ }^{171}$. Należy dodać, że już w 1936 r. w czasopiśmie tym opublikował swój artykuł pt. Archiwum Diecezjalne przy Kurii Biskupiej ob. łac. w Przemyślu ${ }^{172}$.

Mając na sercu sprawy archiwów kościelnych w całej Polsce, przemyski naukowiec nie tylko prowadził prelekcje czy publikował, lecz również próbował wpłynąć na pewne decyzje w tej kwestii poprzez bezpośrednie interwencje. We wrześniu 1930 r. spotkał się w Brzozowie z kardynałem Augustem Hlondem ${ }^{173}$, starając mu się naświetlić problematykę ${ }^{174}$. W korespondencji z ks. J. Fijałkiem tak relacjonował tę rozmowę: „Przed chwilą miałem dłuższą rozmowę z kard. Prymasem Hlondem, który tu jeszcze bawi przed przejażdżką na swój jubileusz do Przemyśla. Przedstawiłem mu moje troski o archiwa diecezjalne w Polsce, które tu i ówdzie się organizuje, ale gdzie indziej są w zaniedbaniu, gdzie indziej nawet w poniewierce. Exempla: Lublin przeniósł swe archiwum do lokalu gorszego niż przedtem, a to samo zrobiła kuria krakowska potrzebując lokalu archiwum na jakąś kancelarię. Lwowska zaś kapituła swoje archiwum oddała w depozyt do uniwersytetu. Niedawno jeden z naszych księży, mój uczeń, poszukując materiałów do monografii swej parafii (Czudec) zwrócił się do krakowskiej kurii i dostał odpowiedź, aby się nie fatygował do Krakowa, bo dla braku lokalu i etatu na archiwistę, archiwum kurii jest niedostępne. Otóż prosiłem prymasa, aby zanim do porządków archiwów kościelnych zabiorą się archiwiści świeccy, zainteresował Episkopat tą sprawą i dopomógł biskupom do organizacji kursu archiwistycznego przez kilka lub kilkanaście dni, dla delegatów z diecezyj”'175. Z kolei w lutym 1932 r. wystosował pismo do Wiceministra i Podsekretarza stanu w Ministerstwie Wyznań Religijnych i Oświecenia Publicznego, ks. prof. Bronisława Żongołłowicza ${ }^{176}$, dołączając do

${ }^{171}$ J. Kwolek, Archiwa - przeszłości skarbnice, „Ateneum Kapłańskie”, R. 21: 1935, t. 36, s. 524-528.

${ }^{172}$ Idem, Archiwum Diecezjalne przy Kurii Biskupiej ob. łac. w Przemyślu, „Ateneum Kapłańskie", R. 22: 1936, t. 38, s. 514-526.

${ }^{173}$ August Hlond - urodził się 5 VII 1881 r. w Brzęczkowicach, był uczniem gimnazjów salezjańskich, a następnie wstąpił do tego zgromadzenia. Od 1897 r. studiował filozofię na Uniwersytecie Gregoriańskim w Rzymie i w 1900 r. uzyskał doktorat. W 1905 r. w Krakowie przyjął święcenia kapłańskie. W 1922 r. został administratorem apostolskim polskiej części Śląska, a w 1925 r. ustanowiono go biskupem katowickim. Dnia 24 VI 1926 r. został arcybiskupem gnieźnieńsko-poznańskim i prymasem Polski. W 1927 r. otrzymał godność kardynała. W latach II wojny światowej przebywał poza Polską, powrócił do kraju 20 VII 1945 r. Zmarł 22 X 1948 r. w Warszawie. Zob. S. Kosiński, Hlond August, [w:] EK, t. 6, Lublin 1993, kol. 1088-1090.

${ }^{174}$ J. Patryn, op. cit., s. 87-88.

${ }^{175}$ Polska Akademia Umiejętności Biblioteka Narodowa PAU i PAN w Krakowie, sygn. 4685, Korespondencja Jana Kwolka z Janem Fijałkiem, List ks. Jana Kwolka do ks. Jana Fijałka z dnia 20 IX 1930 r.

${ }^{176}$ Bronisław Żongołłowicz - urodził się 29 XI 1869 r. (lub 1870) w Datnowie k. Kowna. W 1887 r. wstąpił do Seminarium Duchownego w Kownie, a w 1891 r. rozpoczął studia w Akademii Duchownej w Petersburgu. W 1895 r. przyjął święcenia kapłańskie. Od 1915 r. wykładowca prawa w Akademii Duchownej w Petersburgu, gdzie dwa lata później uzyskał doktorat, a następnie przeniósł się do Lublina obejmując funkcję wykładowcy i dziekana tworzonego Wydziału Prawa Kanonicznego Katolickiego Uniwersytetu Lubelskiego. W 1930 r. został wiceministrem (podsekretarzem stanu) w Ministerstwie Wyznań Religijnych i Oświecenia Publicznego. W latach 1930-1935 był posłem na sejm. W 1936 r. przeszedł na emeryturę i prowadził badania naukowe z zakresu historii Kościoła. Zmarł 30 XI $1944 \mathrm{r}$. w Wilnie. Zob. S. Brzozecki, Żongołłowicz Bronisław, [w:] EK, t. 20, Lublin 2014, kol. 1606-1607; T. Krahel, Żongołlowicz Bronistaw, [w:] SPTK, t. 7, red. L. Grzebień, Warszawa 1983, s. 501-503. 
niego również swój referat o organizacji archiwów kościelnych i sprawozdania archiwalne za lata 1927-1931 ${ }^{177}$. Gdy te zabiegi nie odniosły pożądanego skutku, w maju 1936 r. przesłał memoriał do nuncjusza apostolskiego w Polsce Franciszka Marmaggiego ${ }^{178}$, w którym postulował utworzenie archiwum kościelnego w każdej diecezji i skoncentrowania w nim dokumentów parafialnych sprzed 1800 r., co miało zabezpieczyć je przed zniszczeniem. Dodać należy, że jeszcze w marcu 1934 r. podobne uwagi przedłożył przemyski archiwista biskupowi F. Bardzie, gdy ten prosił go o propozycje ustaw do najbliższego synodu plenarnego ${ }^{179}$. Prawdopodobnie między innymi zabiegi ks. J. Kwolka przyczyniły się do zatwierdzenia144 artykułu synodu plenarnego w 1936 r., który wzywał rządców diecezji do przechowywania dokumentów, książek i przedmiotów zabytkowych w archiwach i muzeach, zaś proboszczów do roztoczenia opieki nad archiwaliami parafialnymi ${ }^{180}$.

Całokształt działalności archiwalnej ks. J. Kwolka, a zwłaszcza jego troska o zasoby kościelne w całym kraju sprawiły, że w środowisku polskich archiwistów cieszył się bez wątpienia sporym autorytetem. On sam pisał o tym w liście datowanym na 7 czerwca 1936 r. do ks. J. Fijałka w następujący sposób: „Był tu u mnie w powrocie ze Lwowa (Tow. Hist.) Wincenty Łopaciński ${ }^{181}$ z Warszawy, zwiedzał archiwum (...), odwiedził i ordynariusza z komplementami na temat archiwum i archiwisty (nic mi jednak potem biskup nie powiedział), omawialiśmy zresztą plany redakcyjne działu archiwistyki kościelnej w «Ateneum Kapłańskim». Widzę, że z Warszawy niektórzy patrzą na mnie jak na autorytet $\mathrm{w}$ tych sprawach. Świeżo proponują mi abym przyjął parę wykładów w projektowanym na jesień

${ }^{177}$ AAPrz, Teki archiwalne - korespondencja 1931-1932, Pismo ks. Jana Kwolka do Wiceministra i Podsekretarza stanu w Ministerstwie Wyznań Religijnych i Oświecenia Publicznego z dnia 8 II 1932 r. (kopia), b. sygn.

${ }^{178}$ Franciszek Marmaggi - urodził się 31 VIII 1876 r. w Rzymie. Święcenia kapłańskie otrzymał w 1900 r., studiował w Seminario Pontificio w Rzymie, gdzie uzyskał doktorat z teologii i prawa kanonicznego. W 1920 r. został mianowany arcybiskupem tytularnym Adrianopola, był nuncjuszem w Rumunii, Czechosłowacji (1923-1925), a od 1927 do 1935 r. w Polsce. Po powrocie do Rzymu został kardynałem, a w 1939 r. prefektem Kongregacji Soboru. Zmarł w Rzymie 3 XI 1949 r. Zob. Z. Zieliński, Marmaggi Francesco, [w:] EK, t. 11, Lublin 2006, kol. 1419-1420.

${ }^{179}$ J. Patryn, op. cit., s. 88-89.

${ }^{180}$ Pierwszy Synod Plenarny w Rzeczypospolitej Polskiej, Warszawa 1936, art. 144, par. 1 i 2.

${ }^{181}$ Wincenty Łopaciński - urodził się 3 X 1886 r. w Warszawie. W 1906 r. zdał egzamin dojrzałości w prywatnej szkole gen. Pawła Chrzanowskiego w Warszawie i rozpoczął na Uniwersytecie Jagiellońskim w Krakowie studia z zakresu historii. W 1910 r. uzyskał absolutorium, a w 1913 r. obronił doktorat. W marcu 1917 r. został mianowany referentem do spraw historyczno-dyplomatycznych w Departamencie Spraw Politycznych Tymczasowej Rady Stanu, a w kwietniu 1918 r. przeszedł na stanowisko archiwisty objazdowego w Wydziale Archiwów Państwowych Ministerstwa Wyznań Religijnych i Oświecenia Publicznego. Zaangażował się w wojnie polsko-bolszewickiej 1920 r. Od 1926 r. był dyrektorem Archiwum Oświecenia Publicznego. Odznaczony Krzyżem Oficerskim Orderu Polonia Restituta. Zmarł nagle 22 IV 1939 r. Zob. S. Konarski, Łopaciński Wincenty Franciszek, [w:] PSB, t. 18, Wrocław-Warszawa-Kraków 1973, s. 402-404. 
kursie dla księży archiwistów"182. O szacunku wobec naukowych dokonań ks. J. Kwolka na polu archiwistycznym świadczy także jego obecność na różnego rodzaju wydarzeniach gromadzących wybitnych przedstawicieli tej dyscypliny. Przykładowo w kwietniu 1928 r. wziął udział w zjeździe i obradach archiwistów w Płocku, połączonych z otwarciem i poświęceniem biblioteki i archiwum diecezjalnego, a miesiąc później uczestniczył w obchodach stulecia „Ossolineum” we Lwowie ${ }^{183}$. Poza tym o archiwum diecezjalnym, jak i osobie jego dyrektora, ukazywały się pochlebne wzmianki w artykułach naukowych i w prasie, o czym informował on na łamach sprawozdan ${ }^{184}$.

\section{Zakończenie}

Ojciec Święty Franciszek w swojej posynodalnej adhortacji Christus Vivit napisał między innymi: „bardzo mnie boli, że niektórzy proponują młodym ludziom budowanie przyszłości bez korzeni, jakby świat zaczął się w tej chwili”. Słowa te niewątpliwie można odczytać jako wyraz papieskiego pragnienia odkrycia na nowo źródeł nie tylko naszej wiary, ale również współczesnej kultury, opierającej się na fundamencie wielowiekowego dziedzictwa przodków. Stwierdzenie to można zarazem potraktować jako ostrzeżenie przed zaprzepaszczaniem skarbów mądrości, wypływających z właściwego odczytania naszej tradycji i kultury, co niewątpliwie oznaczałoby zarazem utratę duchowej i kulturowej tożsamości. Choć bohater niniejszego artykułu żył kilkadziesiąt lat przed rozpoczęciem pontyfikatu obecnego papieża, to niewątpliwie z całą odpowiedzialnością mógłby podpisać się pod tymi treściami papieskiego nauczania, gdyż swoim życiem i pracą udowodnił, z jakim szacunkiem odnosił się do historii i jej źródeł. Ksiądz J. Kwolek, parafrazując słowa następcy świętego Piotra, zdawał sobie sprawę, że diecezja przemyska „nie zaczęła się w tej chwili”, ale niesie ona ze sobą dziedzictwo kilku wieków istnienia. Owo dziedzictwo zostało zapisane nie tylko poprzez wiarę przekazywaną z pokolenia na pokolenie, nie tylko przez budynki sakralne i dzieła sztuki, ale również przez liczne dokumenty, wytwarzane przez kancelarię biskupią, parafie, zakony i rozliczne instytucje kościelne. To właśnie one świadczą o działalności eklezjalnej na tym terenie i dają dziś podstawę do prób jej odtworzenia. Wspomniane dokumenty - jak już mogliśmy się przekonać - przeżywały koleje losu właściwe proweniencji terytorialnej, z której pochodziły, a więc klęski żywiołowe, najazdy i wojny. To wszystko niewątpliwie musiało wywierać wpływ na stan ich zachowania czy nawet zniszczenie. Niemniej jednak wiele z nich przetrwało, a nie byłoby to możliwe bez ludzi, którzy na danym etapie dziejów uświadomili sobie

${ }^{182}$ Polska Akademia Umiejętności Biblioteka Naukowa PAU i PAN w Krakowie, sygn. 4685, Korespondencja Jana Kwolka z Janem Fijałkiem, List ks. Jana Kwolka do ks. Jana Fijałka z dnia 7 VI $1936 \mathrm{r}$.

${ }^{183}$ Sprawozdanie 1927 i 1928, s. 74.

${ }^{184}$ Sprawozdanie 1929, s. 59-60; Sprawozdanie 1930, s. 47-48; Sprawozdanie 1933, s. 84. 
ich wartość dla przyszłych pokoleń, nie zawahali się poświęcić na ten cel własnych funduszy i czasu. Do nich należy zaliczyć - wspomnianych już w artykule - ks. F. Alembeka, ks. B. Chodzińskiego i wielu innych.

Takim człowiekiem, którego Pan Bóg opatrznościowo postawił na czele przemyskiego archiwum, był ks. J. Kwolek. Funkcję archiwariusza kurialnego otrzymał w 1918 r., a więc w czasie, gdy Polacy przystąpili to odtwarzania swojej państwowości, która mogła być zachowana nie tylko dzięki niezależności politycznej czy gospodarczej, ale - co pokazały zabory - przede wszystkim dzięki uświadomieniu narodowi polskiemu jego tożsamości i pamięci historycznej. Doskonale zdawał sobie $\mathrm{z}$ tego sprawę przemyski archiwista, stąd też starał się do nowej rzeczywistości przystosować powierzone sobie zasoby. Nie było to sprawą łatwą, gdyż w tym czasie w Polsce w zasadzie nie istniały teoretyczne opracowania czy zasady omawiające te kwestie. Mimo to ks. J. Kwolek, jako pionier wędrujący po dotychczas nieuczęszczanej ziemi, zdołał przenieść zagraniczne wzorce na grunt polski, przyczyniając się tym samym do rozwoju tej dziedziny wiedzy. Przede wszystkim jednak oddał nieocenione zasługi archiwum przemyskiemu, doprowadzając do jego erygowania, opracowując Statut organizacyjny i Regulamin pracowni, a przede wszystkim porządkując zasoby i powiększając je przez pozyskiwanie starych dokumentów z parafii, instytucji i rąk prywatnych. Oprócz tego zadbał o zaplecze lokalowe, zorganizował pracownię, bibliotekę i otworzył podwoje archiwum dla badaczy z całej Polski. Wszystko to było możliwe dzięki ogromnej ofierze kosztem swojego czasu prywatnego, a nawet zdrowia, o czym świadczą listy do ks. J. Fijałka. W czasie urlopu spędzanego w lesie brzozowskim w sierpniu 1927 r. pisał: „Dłubię tu trochę w mojej archiwistyce, a po sąsiednich plebaniach przy sposobności szperam wychwytując to i owo dla archiwum i muzeum diecezjalnego" 185 . Rok później tak przedstawiał swój stan: „Teraz czuję więcej niż dawniej potrzebę wypoczynku, bo czuję ogólne osłabienie. Może za dużo siedzę codziennie w archiwum, zajęty wertowaniem papierów w warunkach niehigienicznych" 186 .

To nadwątlone tytaniczną pracą zdrowie, jak i przeżycia wojenne związane z utratą sporej części archiwaliów sprawiły, że w momencie ukończenia siedemdziesięciu lat życia przemyski archiwista postanowił zrezygnować z powierzonej mu funkcji. W dniu swoich urodzin pisał do bpa F. Bardy: „Kończąc w dniu dzisiejszym 70 lat życia jestem świadom, że wobec nadwątlonego zdrowia nie mogą dłużej pełnić należycie obowiązków Dyrektora Archiwum Diecezjalnego. Dlatego z urzędu tego (powierzonego mi dekretem śp. ks. bpa Józefa Sebastiana z dnia 19.8.1918) niniejszym rezygnuję i proszę Waszą Ekscelencję o wyznaczenie młodszego następcy"187.

${ }^{185}$ Polska Akademia Umiejętności Biblioteka Naukowa PAU i PAN w Krakowie, sygn. 4685, Korespondencja Jana Kwolka z Janem Fijałkiem, List ks. Jana Kwolka do ks. Jana Fijałka z dnia 24 VIII 1927 r.

${ }^{186}$ Ibidem, List ks. Jana Kwolka do ks. Jana Fijałka z dnia 31 VIII 1928 r.

${ }^{187}$ AAPrz, sygn. APK TP ks. Kwolek Jan, Pismo ks. Jana Kwolka do bpa Franciszka Bardy $\mathrm{z}$ dnia 13 XII $1955 \mathrm{r}$. 
Rządca diecezji jeszcze tego samego dnia odpowiedział na to pismo w następujący sposób: „Z okazji 70-lecia przesyłam Przewielebnemu Ks. Prałatowi najlepsze życzenia, aby Pan Bóg w Swej dobroci na długi jeszcze żywot błogosławił Ks. Prałatowi i wszystkimi darami ubogacał Go ku chwale Kościoła św. i naszej diecezji. Cieszę się, że Przewielebny Ks. Prałat pomimo dolegliwości trzyma się na siłach i nie ustaje w pracy, z której korzysta nie tylko nasza lecz i inne diecezje.

Wśród licznych zasług niepoślednią jest stworzenie i uporządkowanie Archiwum Diecezjalnego, które posiada swoje piękne imię w Polsce.

To też przykrą dla mnie jest rezygnacja Przewielebnego Ks. Prałata z urzędu Dyrektora Archiwum Diecezjalnego. Nie mogę jednak nie uznać powodów, skłaniających Go do powyższego aktu.

Uwzględniając nadwyrężone zdrowie Ks. Prałata, zwalniam Go z urzędu Dyrektora Archiwum Diecezjalnego, wyrażając Mu najwyższe uznanie i podziękę za wieloletnią i nader żmudną pracę archiwalną, która chlubnie przechodzi do historii naszej diecezji.

Proszę Przewielebnego Ks. Prałata, aby zechciał służyć nadal radą Swemu następcy"188.

Ksiądz J. Kwolek po przejściu na emeryturę przeżył jeszcze niespełna trzy lata. Wraz z jego śmiercią dobiegła końca pewna epoka w dziejach Archiwum Diecezjalnego w Przemyślu; epoka, w trakcie której mało znane archiwum prowincjonalnej diecezji zaczęło w Polsce być postrzegane jako wzór dla tego rodzaju instytucji. Stało się to możliwe dzięki niekwestionowanym wysiłkom, zdolnościom i zaangażowaniu bohatera niniejszego artykułu, który - mimo braku wykształcenia w tej specjalności - znalazł swoje miejsce w panteonie polskich historyków i archiwistów.

${ }^{188}$ Ibidem, Pismo bpa Franciszka Bardy do ks. Jana Kwolka z dnia 13 XII 1955 r. 


\section{Bibliografia}

\section{Źródla archiwalne:}

Archiwum Archidiecezjalne w Przemyślu:

sygn. APK TP ks. Kwolek Jan, Teczka służbowa ks. Jana Kwolka

Okólniki bpa Franciszka Bardy, b. sygn.

Okólniki diecezji przemyskiej 1939-1947, b. sygn.

Okólniki diecezji przemyskiej 1948-1949, b. sygn.

Tabela służbowa ks. Hieronima Kocyłowskiego, b. sygn.

Tabela służbowa ks. Jana Kwolka, b. sygn.

Teczka „Archiwum. Zabranie i starania o zwrot”, b. sygn.

Polska Akademia Umiejętności Biblioteka Naukowa PAU i PAN w Krakowie:

sygn. 4685, Korespondencja Jana Kwolka z Janem Fijałkiem

\section{Zbiory autora:}

Relacja ks. Henryka Borcza (71 1.), Przemyśl, 11 VI 2021 r.

\section{Źródla drukowane:}

Acta et Statuta Synodi dioecesanae Premisliensis quam A. D. 1902, Diebus 19, 20, 21, 22 mensis habuit Josephus Sebastianus Pelczar Episcopus Premisliensis Latinorum [...], Premisliae 1903.

Archiwum diecezjalne, KDP 1928, R. 28, z. 8-9, s. 181.

Archiwum diecezjalne, KDP 1929, R. 29, z. 3-4, s. 60.

Archiwum diecezjalne poszukuje, KDP 1931, R. 31, z. 1, s. 25-26.

Archiwum diecezjalne poszukuje, KDP 1932, R. 32, z. 1, s. 35.

Archiwum Diecezjalne Przemyskie w latach 1927 i 1928. (Sprawozdanie archiwisty), KDP 1929, R. 29 , z. 3-4, s. 67-74.

Archiwum Diecezjalne Przemyskie w roku 1929. (Sprawozdanie archiwisty), KDP 1930, R. 30, z. 1, s. 59-62.

Archiwum Diecezjalne Przemyskie w roku 1930. (Sprawozdanie archiwisty), KDP 1931, R. 31, z. 1, s. 46-51.

Archiwum Diecezjalne Przemyskie w roku 1931. (Sprawozdanie archiwisty), KDP 1932, R. 32, z. 1, s. 30-35.

Archiwum Diecezjalne Przemyskie. Sprawozdanie za rok 1932, KDP 1933, R.33, z. 1, s. 21-25.

Archiwum Diecezjalne Przemyskie. Sprawozdanie za rok 1933, KDP 1934, R. 34, z. 3, s. 81-85.

Archiwum Diecezjalne Przemyskie. Sprawozdanie za rok 1934, KDP 1935, R. 35, z. 5-6, s. 95-98.

Archiwum Diecezjalne Przemyskie. Sprawozdanie za rok 1935, KDP 1936, R. 36, z. 6, s. 201-203.

Archiwum Diecezjalne Przemyskie. Sprawozdanie za rok 1936, KDP 1937, R. 37, z. 2-4, s. 114-116.

Codex Iuris Canonici, Romae 1917.

Księgi metrykalne, KDP 1948, R. 41, z. 2-3, s. 44.

Lettera circolare di Sua Eminenza Rev. Il. Sig. Cardinale Gaspari ai Vescovi d'Italia per la conservazione, custodia e uso degli Archivi e delle Biblioteche ecclesiastiche, Roma 1923.

Pierwszy Synod Plenarny w Rzeczypospolitej Polskiej, Warszawa 1936.

Przypomnienie o ekstraktach metrykalnych, KDP 1929, R. 29, z. 3-4, s. 58.

Przypomnienie o odsyłaniu archiwaliów, KDP 1927, R. 27, z. 2, s. 59.

Regulamin pracowni Archiwum diecezjalnego przy Kurii Biskupiej o. t. w Przemyślu, w: J. Kwolek, Archiwa diecezji przemyskiej ob. łac., Przemyśl 1927, s. 65-68.

Rocznik diecezji przemyskiej ob. łac. na rok 1938, Przemyśl 1938. 
Rozporzadzenie o ekstraktach metrykalnych, KDP 1928, R. 28, z. 10-11, s. 222-223.

Rozporzadzenie w sprawie archiwów, KDP 1927, R. 27, z. 2, s. 57-58.

Schematismus universi venerabilis cleri saecularis et regularis dioecesis premisliensis rit. lat. pro anno Domini 1932, Premisliae 1932.

Statut organizacyjny Archiwum diecezjalnego przy Kurii Biskupiej o. t. w Przemyślu, w: J. Kwolek, Archiwa diecezji przemyskiej, s. 61-64.

\section{Opracowania:}

Archiwum Archidiecezjalne w Przemyślu, w: Archiwa Kościoła katolickiego w Polsce. Informator, oprac. M. Dębowska, Kielce 2002, s. 83-89.

J. Ataman, Ks. Jan Kwolek 1885-1958, [w:] ABMK, t. 1, z. 1, Lublin 1959, s. 159-164.

D. Bialic, Pawłowski Franciszek Ksawery, [w:] PSB, t. 25, Wrocław 1980, s. 497-498.

H. Borcz, Nowak Anatol, [w:] EK, t. 14, Lublin 2010, kol. 30-31.

S. Brzozecki, Żongołłowicz Bronisław, [w:] EK, t. 20, Lublin 2014, kol. 1606-1607.

K. Gabriel, Zachariasiewicz Franciszek (1770-1845), [w:] SPTK, t. 4, Warszawa 1983, s. 496-498.

E. Gigilewicz, Krzysztof Andrzej Jan Szembek herbu Szembek, [w:] Arcybiskupi i biskupi przemyscy. Słownik biograficzny, red. A. Szal, H. Borcz, M. Kapłon, S. Zych, Przemyśl-Rzeszów 2021, s. 155-159.

E. Gigilewicz, Szembek Krzysztof Jan, [w:] EK, t. 19, Lublin 2013, red. 2013, kol. 37-38.

M. Kociubiński, Księża diecezji przemyskiej obrządku łacińskiego, t. 1, wstęp i opr. Z. Budzyński, Przemyśl 1988-1989 [mps w AAPrz].

S. Konarski, Łopaciński Wincenty Franciszek, [w:] PSB, t. 18, Wrocław-Warszawa-Kraków 1973, s. $402-404$.

S. Kosiński, Hlond August, [w:] EK, t. 6, Lublin 1993, kol. 1088-1090.

J. Kracik, Fijałek Jan Nepomucen, [w:] SPTK, t. 5, red. L. Grzebień, Warszawa 1983, s. 374-383.

T. Krahel, Żongołłowicz Bronisław, [w:] SPTK, t. 7, red. L. Grzebień, Warszawa 1983, s. 501-503.

S. Krzywiński, Działalność duszpasterska Józefa Sebastiana Pelczara biskupa przemyskiego w latach 1899-1924, Przemyśl 2003.

B. Kumor, Potoczki Antoni Jan, [w:] SPTK, t. 3, red. H. E. Wyczawski, Warszawa 1982, s. 429-430.

J. Kwolek, Alembek (Alnpech), [w:] PSB, t. 1, Kraków 1935, s. 73-74.

J. Kwolek, Archiwa diecezji przemyskiej ob. łac., Przemyśl 1927.

J. Kwolek, Archiwa - przeszłości skarbnice, „Ateneum Kapłańskie”, R. 21: 1935, t. 36, s. 524-528.

J. Kwolek, Archiwum diecezjalne przy Kurii Biskupiej ob. łac. w Przemyślu, Włocławek 1936.

J. Kwolek, Archiwum Diecezjalne przy Kurii Biskupiej ob. łac. w Przemyślu, „Ateneum kapłańskie”, T. 38: 1936, s. 514-526.

J. Kwolek, Ekstrakty metrykalne w Archiwum Diecezjalnem Przemyskiem, KDP 1928, R. 28, z. 10-11, s. 231-249.

J. Kwolek, Naukowa organizacja archiwów diecezjalnych, „Archeion”, T. 4: 1928, s. 15-36.

J. Kwolek, Naukowa organizacja archiwów kościelnych, „Przegląd Teologiczny”, R. 11: 1930, s. 1-37.

J. Kwolek, Śp. Anatol Nowak. Ordynariusz przemyski o. t., KDP 1933, R. 33, z. 4, s. 165-167.

R. Leszczyński, Korczyński Michat, [w:] EK, t. 9, Lublin 2002, kol. 836-837.

R. Leszczyński, Korczyński Michał Tomasz Wincenty, w: PSB, t. 14, Wrocław 1968-1969, s. 52-53.

F. Misiąg, Wspomnienia pośmiertne. Śp. Ks. Infułat dr Stefan Momidłowski (1872-1958), KDP 1959, R. 45, z. 6-8, s. 152-162.

S. Momidłowski, Wspomnienia pośmiertne: Śp. ks. dr Jan Kwolek, KDP 1958, R. 44, z. 9-10, s. 267-272.

P. Nitecki, Biskupi Kościoła w Polsce. Stownik biograficzny, Warszawa 1992.

P. Nitecki, Biskupi Kościoła w Polsce w latach 965-1999. Stownik biograficzny, wyd. 2, Warszawa 2000 . 
E. Ozorowski, Alembek Fryderyk, [w:] SPTK, t. 1, red. H. E. Wyczawski, Warszawa 1981, s. 45-46.

J. Patryn, Archiwistyczna działalność ks. Jana Kwolka (1918-1955), Lublin 1985 [mps w Bibliotece Wyższego Seminarium Duchownego w Przemyślu].

F. Pawłowski, Prałaci i kanonicy Kapituły Katedralnej obrządku łacińskiego w Przemyślu, przekład Z. Trojnar, Przemyśl 2018.

F. Persowski, Kwolek Jan, [w:] PSB, t. 16, red. E. Rostworowski, Wrocław-Warszawa-Kraków 1971, s. 387-388.

T. Pudłocki, Ksiądz doktor Jan Kwolek, „Rocznik Gimnazjalny. I Liceum Ogólnokształcące im. J. Słowackiego w Przemyślu", nr 3 (82), 1998, s. 151-155.

W. Sarna, Dzieje diecezji przemyskiej obrządku łac[ińskiego]. Episkopat przemyski o[brzadku] t[acińskiego], cz. 2, Przemyśl 1910.

W. Semkowicz, Fijatek Jan Nepomucen, [w:] PSB, t. 6, Kraków 1948, s. 441-443.

E. Ślemp, Biblioteki kościelne i klasztorne Przemyśla, [w:] Z dziejów bibliotek przemyskich. Praca zbiorowa z okazji sześćdziesięciolecia Przemyskiej Biblioteki Publicznej (1947-2007), red. A. Siciak, Przemyśl 2009, s. 209-232.

T. Śliwa, Anatol Nowak, [w:] Arcybiskupi i biskupi przemyscy, s. 225-230.

T. Śliwa, Jan Antoni Potoczki (Potocki), [w:] Arcybiskupi i biskupi przemyscy, s. 188-189.

T. Śliwa, Korczyński Michat Tomasz Wincenty, [w:] SPTK, t. 2, red. H. E. Wyczawski, Warszawa 1982, s. 352-355.

T. Śliwa, Kwolek Jan, [w:] SPTK, t. 6, red. L. Grzebien, Warszawa 1983, s. 292-295.

T. Śliwa, Michat Tomasz Wincenty Korczyński, [w:] Arcybiskupi i biskupi przemyscy, s. 190-196.

T. Śliwa, Pelczar Józef Sebastian, [w:] Arcybiskupi i biskupi przemyscy, s. 212-225.

T. Śliwa, Pelczar Józef Sebastian, [w:] PSB, t. 25, Wrocław 1980, s. 547-550.

J. Świeboda J., Dzieje I Gimnazjum w Rzeszowie w latach 1786-1918, Rzeszów 1984.

B. Walicki, Franciszek Ksawery Zachariasiewicz, [w:] Arcybiskupi i biskupi przemyscy, s. 197-198.

H. E. Wyczawski, Pelczar Józef Sebastian, [w:] SPTK, t. 3, red. H. E. Wyczawski, Warszawa 1982, s. 336-345.

Z. Zieliński, Marmaggi Francesco, [w:] EK, t. 11, Lublin 2006, kol. 1419-1420.

S. Zych, Diecezja przemyska obrządku łacińskiego w warunkach okupacji niemieckiej i sowieckiej 1939-1944/45, Przemyśl 2011.

S. Zych, Losy Archiwum Diecezjalnego w Przemyślu w latach II wojny światowej, „Prace Historyczno-Archiwalne", T. 17: 2006, s. 181-188.

S. Zych, Potoczki Jan Antoni bp, [w:] EK, t. 16, Lublin 2012, kol. 117.

S. Zych, Zachariasiewicz Franciszek Ksawery, [w:] EK, t. 20, Lublin 2014, kol. 115. 